\title{
Potential and Economic Analysis of Solar-to-Hydrogen Production in the Sultanate of Oman
}

\author{
Razzaqul Ahshan (iD
}

Citation: Ahshan, R. Potential and

Economic Analysis of

Solar-to-Hydrogen Production in the Sultanate of Oman. Sustainability 2021, 13, 9516. https://doi.org/ $10.3390 /$ su13179516

Academic Editor:

Alberto-Jesus Perea-Moreno

Received: 28 June 2021

Accepted: 12 August 2021

Published: 24 August 2021

Publisher's Note: MDPI stays neutral with regard to jurisdictional claims in published maps and institutional affiliations.

Copyright: (C) 2021 by the author. Licensee MDPI, Basel, Switzerland. This article is an open access article distributed under the terms and conditions of the Creative Commons Attribution (CC BY) license (https:// creativecommons.org/licenses/by/ $4.0 /)$.
Department of Electrical and Computer Engineering, College of Engineering, Sultan Qaboos University, Al-Khoud 123, Oman; razzaqul@squ.edu.om

\begin{abstract}
Hydrogen production using renewable power is becoming an essential pillar for future sustainable energy sector development worldwide. The Sultanate of Oman is presently integrating renewable power generations with a large share of solar photovoltaic (PV) systems. The possibility of using the solar potential of the Sultanate can increase energy security and contribute to the development of the sustainable energy sector not only for the country but also for the international community. This study presents the hydrogen production potential using solar resources available in the Sultanate. About 15 locations throughout the Sultanate are considered to assess the hydrogen production opportunity using a solar PV system. A rank of merit order of the locations for producing hydrogen is identified. It reveals that Thumrait and Marmul are the most suitable locations, whereas Sur is the least qualified. This study also assesses the economic feasibility of hydrogen production, which shows that the levelized cost of hydrogen $(\mathrm{LCOH})$ in the most suitable site, Thumrait, is $6.31 \mathrm{USD} / \mathrm{kg}$. The LCOH in the least convenient location, Sur, is $7.32 \mathrm{USD} / \mathrm{kg}$. Finally, a sensitivity analysis is performed to reveal the most significant influential factor affecting the future's green hydrogen production cost. The findings indicate that green hydrogen production using solar power in the Sultanate is promising, and the $\mathrm{LCOH}$ is consistent with other studies worldwide.
\end{abstract}

Keywords: green hydrogen; solar photovoltaic; renewable energy; economic feasibility; sensitivity analysis; Sultanate of Oman

\section{Introduction}

\subsection{General and Motivation}

Decarbonisation is one of the critical efforts countries worldwide take to reduce the risk of a global threat called climate change. The energy sector plays an essential role in the decarbonisation effort by integrating renewable power generations. By the end of 2020, the aggregated installed capacity of renewable power generation has reached $2799 \mathrm{GW}$, which has the largest share of hydroelectric, solar, and wind power. In 2020 , more than $80 \%$ of the new capacity added was from renewable sources, in which solar and wind accounts for about $91 \%$ of new renewables [1,2]. Recently, hydrogen fuel from renewable sources has received significant interest because of its broad-spectrum applicability and ability to enhance the decarbonisation mission. The global hydrogen production capacity by the end of 2020 was 2.3 million tons, which is expected to reach 6.7 million tons by the end of 2030 [3]. Table 1 illustrates various hydrogen fuel applications, including transportation, building, industry, and feedstock [4].

The leading renewable energy technologies are hydro, wind, solar photovoltaic, bioenergy, geothermal, solar thermal, and ocean. Hydro technology has the highest, and Ocean technology reveals the least number of contributions in terms of the energy production index worldwide [5]. Among them, hydro technology has topographic restrictions. The availability of solar resources in most parts of the globe is the highest among all kinds of renewable energies. This energy resource is reported as the most appropriate alternative for fossil fuels [6]. Moreover, solar photovoltaics unfolded a profound reduction in cost 
over $2010-2019$ at $82 \%$, followed by concentrated solar power at $47 \%$, onshore wind at $40 \%$, and offshore wind at 29\% [7]. Thus, solar photovoltaic technology has significant potential for hydrogen production, which can accelerate the decarbonisation process.

Table 1. Synopsis of hydrogen fuel applications [4].

\begin{tabular}{|c|c|}
\hline Application Sector & Applications \\
\hline Transportation & $\begin{array}{l}\text { Compact vehicle for urban transportation; mid-size vehicle with extended range; } \\
\text { lightweight truck/van for urban distribution; medium size vehicle with short-range; } \\
\text { medium-duty truck for regional haul; regional transportation, such as passenger train, } \\
\text { SUV, ferry, and buses. Heavy-duty truck for long haul transportation; large ferries for } \\
\text { vehicles and people; vehicles for commercial uses, such as large passenger vehicles, } \\
\text { buses for long-range transport, coaches for long-distance transportation; forklift, and } \\
\text { synfuels for aviation. }\end{array}$ \\
\hline Heat and power for buildings & $\begin{array}{l}\text { Fuel cell-based combined heat and power (CHP) for old hospitals, old flat city centre, } \\
\text { and new houses; hydrogen boilers for the new home, old flat city centre, and old } \\
\text { hospitals; hybrid heat pump and boiler; and blended application of hydrogen in } \\
\text { natural gas boilers. }\end{array}$ \\
\hline Heat and power for industry & $\begin{array}{l}\text { Fuel cell-based backup and remote power generation; hydrogen furnace for high and } \\
\text { medium grade heat; combined cycle hydrogen turbine; and simple cycle hydrogen } \\
\text { turbine. }\end{array}$ \\
\hline Industry feedstock & $\begin{array}{l}\text { Low-carbon ammonia generation; refining; low-carbon steel-hydrogen DRI; and } \\
\text { methanol production. }\end{array}$ \\
\hline Mobility & $\begin{array}{l}\text { Ships for container, motorbikes, tankers, tractors, off-road applications, fuel cells for } \\
\text { airplanes }\end{array}$ \\
\hline Others & $\begin{array}{l}\text { Backup power systems, large-scale CHP for industry, mine apparatus, metals } \\
\text { processing (non-DRI steel), etc. }\end{array}$ \\
\hline
\end{tabular}

Furthermore, the Sultanate of Oman has considerable potential in generating clean power using renewable sources, such as solar and wind [8-10]. Figure 1 shows the distribution of solar radiation during January and July, respectively [11]. The average wind speed for 28 different locations ranges from 3.0 to $6.3 \mathrm{~m} / \mathrm{s}$ at $10 \mathrm{~m}$ height. Towards decarbonisation, the Sultanate of Oman has set a target to harness $10 \%$ of its energy requirement from renewable sources by 2025 [12]. By 2020, the total installed capacity of renewable power generation in the Sultanate was $159 \mathrm{MW}$ [1]. Among these, the solar power share was about $68.56 \%$, and the rest was from wind resources. Apart from electricity production prospects, such renewable energy resources have enormous potential to produce green hydrogen fuel. Presently, more than $95 \%$ of hydrogen production worldwide comes from fossil fuels [13], which is not an exception in the case of the Sultanate. Furthermore, the economic diversity, grid-scale energy storage requirement, green transportation, and industrialisation in the Sultanate will demand more hydrogen in the future. Moreover, the Sultanate can utilise the renewable potential for large-scale hydrogen production, which will meet the local demand and prepare the Sultanate as a hydrogen exporter. Thus, it is essential to investigate the potential of producing green hydrogen and the cost of producing hydrogen using renewable resources, particularly solar, in Oman. 


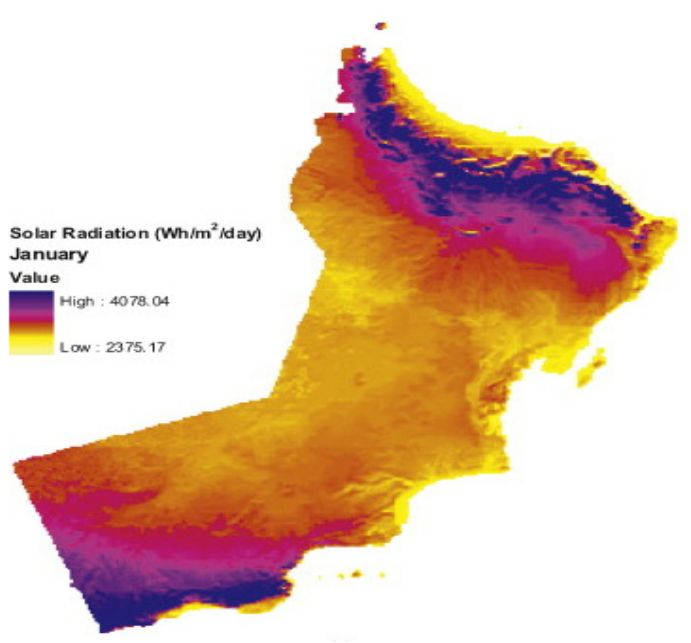

(a)

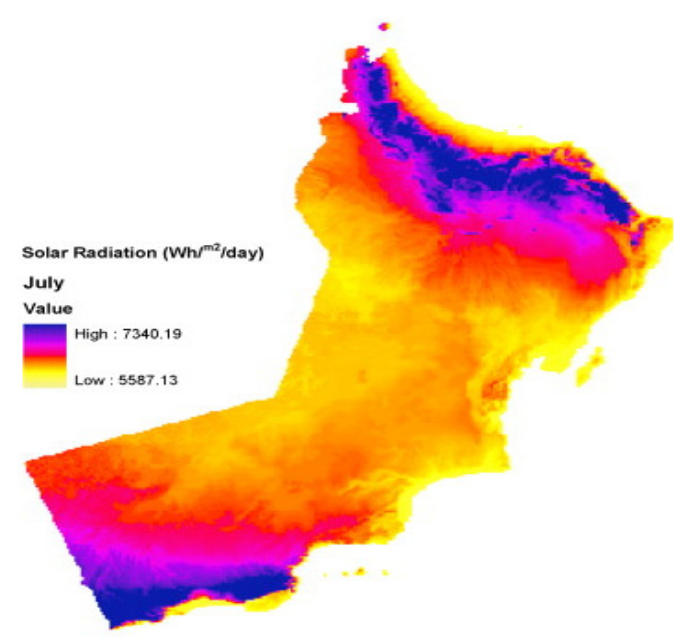

(b)

Figure 1. Distribution of solar resources in the Sultanate of Oman: (a) 2.375 to $4.078 \mathrm{~kW} / \mathrm{m}^{2} /$ day in January, (b) 5.587 to $7.34 \mathrm{~kW} / \mathrm{m}^{2} /$ day in July. Reprinted with permission from ref. [11], @2009, Elsevier Ltd.

\subsection{Related Work}

Hydrogen generation depends upon the production process and primary fuels or resources $[14,15]$. One way to produce hydrogen is to use renewable sources and an electrolysis process called green hydrogen. The hydrogen generated from fossil fuels using a reformer with no carbon dioxide $\left(\mathrm{CO}_{2}\right)$ mitigation is grey or black hydrogen. In addition, blue hydrogen is generated using fossil fuels and a reformer, Steam Methane Reforming (SMR), with $\mathrm{CO}_{2}$ relief, whereas pink hydrogen is produced using nuclear power and the electrolysis process. Grey hydrogen production generates a substantial greenhouse gas released directly into the atmosphere [16]. The blue hydrogen production process captures or stores $\mathrm{CO}_{2}$ for later use [17]. The $\mathrm{CO}_{2}$ capture, utilisation, and storage mechanism increase the total capital cost of the process, and hence the hydrogen production cost. However, a high-capacity $\mathrm{CO}_{2}$ electrolyser and storage $\mathrm{CO}_{2}$ for formic acid production combined in the blue hydrogen production process can reduce the cost of blue hydrogen [18]. Blue hydrogen can play a vital role as a low-emission (not zero emission because of methane leakage [19]) energy carrier for countries where renewable-based green hydrogen cannot meet the low-carbon hydrogen demand [15]. However, this hydrogen production comes from fossil fuels, such as natural gas, coal, and oil. Moreover, the volatile gas price, lockin fossil fuel price, depleted fossil fuel reserve, and geopolitical issues may restrict the development of blue hydrogen production.

Green hydrogen production using renewable powers involves three steps: Process primary energy (solar and wind) to produce electricity, ensure compatible and adequate electricity supply to the electrolyser, and generate hydrogen. Figure 2 depicts the renewablesource-based hydrogen production process using water electrolysis. The technologies for water electrolysis are an alkaline electrolyser, a polymer electrolyte membrane (PEM) electrolyser, and a solid oxide electrolyser cell. Alkaline is the earliest and most mature technology; however, it faces challenges, such as losses during operation at the high current densities that result in a rise in operating temperature and lessens efficiency [20,21], and the possibility of mixing hydrogen and oxygen gases while passing through the aqueous electrolyte. The solid oxide electrolyser cell (SOEC) has the highest efficiency; however, this technology market is still in the early stages [22]. The PEM electrolyser can operate at higher-level pressures, resolving the issue of aqueous electrolytes in the alkaline electrolyser [21]. Moreover, the polymer electrolysers can perform with electricity from stochastically varying renewable sources, such as solar and wind [22-26]. This study selects the PEM electrolyser because of its ability to perform under intermittent input power, cost, efficiency, and commercial viability [23,24,27-29]. 


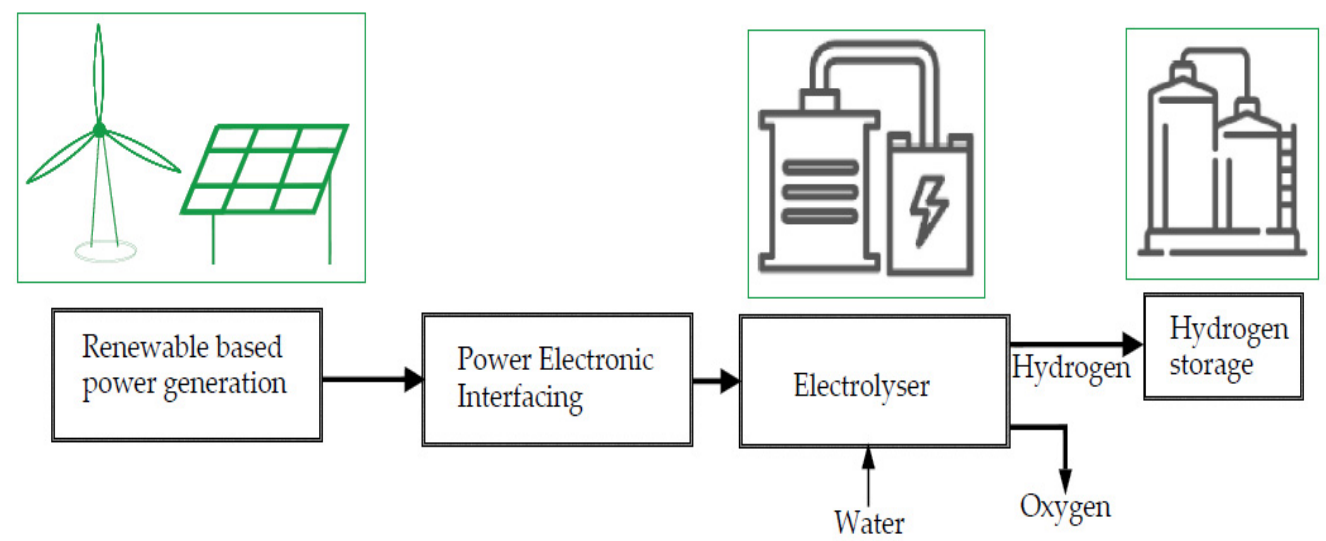

Figure 2. Hydrogen production stages utilising renewable power sources.

The key drivers for renewable-based hydrogen production are technological readiness, significant potential for decarbonisation, freely available primary energy sources, and broad-spectrum applicability. However, the cost of hydrogen production using renewable sources can be a real obstacle to deploy green hydrogen projects for a country or stakeholder. Therefore, the hydrogen production cost evaluation is an essential element to assess the potential of hydrogen generation from intermittent renewable sources. Several researchers have estimated the green hydrogen generation cost using the notion adopted from the levelized cost of energy (LCOE) [30]. A feasibility study of hydrogen production using wind power is presented in [31-34], which showed the hydrogen production cost using electrolyser technology in the range of 10.15-7.55 USD/kg. A study in [23] reveals that wind power-based hydrogen production costs range from 16.1 to $8.5 \mathrm{USD} / \mathrm{kg}$ at 50 and $100 \mathrm{~m}$ hub heights. The utilisation of excess wind power for hydrogen production in a grid-connected system is evaluated in [35], and the hydrogen production cost was reported at 10.08 USD $/ \mathrm{kg}$. In [36], wind-powered hydrogen production's economic analysis indicates the price of $10.98 \mathrm{USD} / \mathrm{kg}$. This cost can be reduced by $50 \%$ if the electricity from the grid is supplied to the electrolyser. An economic investigation of a wind-hydrogenbattery-based hydrogen production study indicates the price of hydrogen production to be $9.0 \mathrm{USD} / \mathrm{kg}[37]$.

Techno-economic analysis of solar hydrogen generation using parabolic dish technology is presented in [38], and the hydrogen production cost was in the range of 7.19 to 11.09 USD $/ \mathrm{kg}$. The feasibility of concentrated solar power-based hydrogen production is evaluated. It shows that the cost of hydrogen production is $15.92 \mathrm{USD} / \mathrm{kg}$ in the base case, which can be reduced to $8.14 \mathrm{USD} / \mathrm{kg}$ in the best-case scenario [39]. A combination of a parabolic trough concentrator and the solar photovoltaic system is analysed for the hydrogen production capacity of the studied system; however, the cost of hydrogen production remains to be determined [40]. In [41], a techno-economic investigation of isolated solar photovoltaic-based hydrogen generation potential is discussed. The cost of hydrogen production is reported at a rate of $3.72 \mathrm{USD} / \mathrm{kg}$, where the capacity factor of the solar photovoltaic system is assumed.

The authors in [42] present a hydrogen production economic analysis using different solar power generation technologies combined with the PEM and alkaline electrolyser. The cost of hydrogen production using solar PV with the PEM electrolyser was at a value of 3.31 USD $/ \mathrm{kg}$, lower than the PV and concentrated solar power-based hydrogen generation. In [43], solar photovoltaic-based hydrogen production is discussed, which indicates that the hydrogen generation cost reduction is possible by improving the system efficiency. Hydrogen production using wind and solar for refuelling stations can cost $2.0 \mathrm{USD} / \mathrm{kg}$ if the electricity cost is $0.01 \mathrm{USD} / \mathrm{kWh}$ [44]. However, the electricity production cost from renewables is yet to reach $0.01 \mathrm{USD} / \mathrm{kWh}$. Hydrogen production using solar power and water electrolysis is evaluated, indicating the prospect of generating green hydrogen; however, the cost of hydrogen production is yet to be determined [45]. 


\subsection{Research Gap, Objectives, and Contributions}

The previous techno-economic studies of renewable hydrogen production assume the capacity factor of the solar PV or wind plants. Such an assumption influences the cost of energy produced from renewable energy sources, affecting hydrogen production cost. The electricity cost is one of the most sensitive factors in assessing hydrogen production economics $[23,25,26,46,47]$. Moreover, the energy estimation using a solar PV system, especially in a hot and humid environment, requires derating factor consideration due to temperature variability [48]. This factor remains unaccounted for if the capacity factor is assumed to estimate the energy output of a solar PV plant. Furthermore, using different solar technologies to produce hydrogen is more focused than a solar PV-based system alone. In addition, the prospect of hydrogen production using the significant solar resource available in the Sultanate is yet to be investigated. Therefore, the potential and economic analysis of producing green hydrogen using solar PV renewable power is the main topic of this paper. The objectives of this study are:

1. To examine the potential of green hydrogen production using the solar resources available in the Sultanate of Oman.

2. To analyse the solar photovoltaic-to-hydrogen production process considering site resources and temperature variability for determining the capacity factor of the photovoltaic plant instead of assuming it.

3. To evaluate the cost of green hydrogen production using the idea of levelized cost and identify the influential cost variables in producing hydrogen using solar power in Omani conditions.

Accomplishing these objectives allows making following contributions:

- A pioneering analysis process of solar photovoltaic-to-hydrogen production potential and cost of hydrogen production that considers the capacity factor determined based on the site resources and temperature variability in the Sultanate of Oman.

- Outlining a rank of suitable locations with the potential of dedicated solar photovoltaicbased hydrogen production facilities development and identifying critical variables that significantly impact hydrogen production cost in Omani conditions.

\subsection{Paper Structure}

The rest of the paper is structured as follows: Section 2 describes the research methodology, i.e., the modelling of PV plant energy output, hydrogen production model, the economic model of the energy cost and hydrogen production cost, and the methodology implementation steps. Then, in Section 3, the results for PV plant energy production, hydrogen production, cost of hydrogen production, and sensitivity analysis are presented and discussed. This section also discusses the technology adoption factors and environmental impact. Finally, Section 4 summarizes the conclusion of the paper that also includes research limitations and future direction.

\section{Methodology}

The methodology of solar photovoltaic-based hydrogen production potential and cost assessment includes estimating the energy output of the PV plant considering the site data and temperature variability effect, quantifying hydrogen production, and performing an economic analysis. In addition, the financial analysis requires modelling of energy and hydrogen production costs to determine the LCOE and LCOH. Finally, a sensitivity analysis is needed to reveal the factors that significantly impact the $\mathrm{LCOH}$.

\subsection{Energy Output Model of a PV Plant}

The annual energy output of a solar PV power plant is calculated as [48],

$$
E_{P V}=P_{r, p v} D_{f} P_{s h} N_{d}
$$


where $E_{P V}$ is the energy output of the PV plant in $\mathrm{kWh}, P_{r, p v}$ is the rated output power of the PV plant in $\mathrm{kW}, D_{f}$ is the overall derating factor, $P_{s h}$ is the daily average peak sun hour, and $N_{d}$ is the number of days in a period, such as in a year. The overall derating factor is composed of two components. They are the derating factor due to the temperature variation and other system components that include the PV module nameplate DC rating, the transformer and inverter, diodes and connections, AC and DC wiring, soiling, shading, system availability, sun tracking, and age. The derating factor due to system components can be a fixed value; however, the derating factor due to temperature variation is modelled to reflect the effect of such variations on the PV output. The present study concentrates on the system that can be developed in hot and humid conditions, where the temperature variation occurs in a wide range. The derating factor is calculated by modelling the actual cell temperature as follows [49],

$$
T_{C}=T_{a}+\left(\frac{T_{N O C T}-20^{\circ} \mathrm{C}}{S_{N O C T}}\right) \times S_{S}
$$

where $T_{C}$ is the real cell operating temperature in ${ }^{\circ} \mathrm{C}, T_{a}$ is the ambient temperature ${ }^{\circ} \mathrm{C}$, $T_{N O C T}$ is the normal operating cell temperature in ${ }^{\circ} \mathrm{C}, S_{S}$ is the site solar intensity in $\mathrm{kW} / \mathrm{m}^{2}$, and $S_{N O C T}$ is the solar intensity at the standard testing condition (STC) in $\mathrm{kW} / \mathrm{m}^{2}$. The amount of reduction in maximum power due to the temperature effect is computed as a percentage as [49],

$$
P_{\text {red }}=\alpha\left(T_{C}-25^{\circ} \mathrm{C}\right)
$$

where $P_{\text {red }}$ is the decrease in maximum output power in percentage and $\alpha$ is the reduction in maximum output power due to each ${ }^{\circ} \mathrm{C}$ variation of the cell temperature in $\% /{ }^{\circ} \mathrm{C}$. Therefore, the derating factor due to module temperature alteration is calculated as

$$
D_{\text {temp }}=1-P_{\text {red }}
$$

Considering the derating factor due to the aforementioned system components as $D_{s y s}$, the overall derating factor can be depicted as

$$
D_{f}=D_{\text {temp }} D_{\text {sys }}
$$

The capacity factor of the PV plant is determined using Equation (6) [49].

$$
\text { Capacity factor }=\frac{E_{P V}}{P_{r, p v} \times 8760}
$$

\subsection{Model of Hydrogen Production}

An electrolyser is an essential device to produce hydrogen from electricity. Figure 1 shows a PV-based hydrogen production system, where the energy output from the PV plant is fed to an electrolyser to generate hydrogen. The hydrogen production using an electrolyser provided by PV power is computed using Equation (7) [35].

$$
H_{P V}=\frac{\eta_{p c} E_{P V}}{E_{E L}}
$$

where $H_{P V}$ is the amount of hydrogen production using PV power in $\mathrm{Nm}^{3}, \eta_{p c}$ is the efficiency of the interfacing power converter between the PV plant and the electrolyser as a percentage, and $E_{E L}$ is the energy required by the electrolyser for one unit volume of hydrogen production in $\mathrm{kWh} / \mathrm{Nm}^{3}$. The hydrogen production in $\mathrm{kg}$ is calculated as [13],

$$
H_{P V, k g}=\frac{H_{P V} \text { in } \mathrm{Nm}^{3}}{11.1}
$$




\subsection{Economic Model}

The economic model of solar-to-hydrogen production requires modelling of solar-toelectricity cost and hydrogen production cost. Unlike if the electrolyser uses electricity from the utility grid, the electricity price is known from the utility company. However, the electricity cost of the renewable source-based power plant is essential to assess in order to utilise it in evaluating hydrogen production cost. The electricity generation cost from renewable sources depends on the resources available on the site and the use of technology [24]. The models of electricity production cost from solar PV and the hydrogen production cost using the electrolyser use the concept of LCOE described in the following subsections.

\subsubsection{Model of Energy Production Cost}

The LCOE approach uses different cost factors, such as a discount rate, capital cost, installation and operation, and maintenance costs, to determine the energy cost. The LCOE for a PV plant is determined by the ratio of the aggregated annualized cost of the PV plant to yearly energy produced from the PV plant, which can be expressed as [23],

$$
L O C E=\frac{C_{P V} C R F_{P V}+C_{p c} C R F_{p c}+C_{i n s} C R F_{i n s}+C_{m i s} C R F_{m i s}+C_{O M}}{E_{P V}}
$$

where $C_{P V}, C_{p c}, C_{i n s}$, and $C_{m i s}$ are the cost of PV panel, interfacing power converter, installation and civil works, and miscellaneous, respectively. $C R F_{P V}, C R F_{p c}, C R F_{i n s}$, and $C R F_{\text {mis }}$ are the cost recovery factors of the PV panel, the interfacing power converter, installation and civil works, and miscellaneous cost, respectively. Equation (9) can be formulated as Equation (10), where $C_{\text {plant }}$ is the total installed cost of the PV plant and $C R F_{\text {plant }}$ is the cost recovery factor for the total installed PV plant cost.

$$
\text { LOCE }=\frac{C_{\text {plant }} C R F_{\text {plant }}+C_{O M}}{E_{P V}}
$$

The accepted total installed cost of a PV plant can be obtained based on the per $\mathrm{kW}$ installed cost $\left(C_{\text {ins } / \mathrm{kW}}\right)$ basis from [7], and it can be expressed as,

$$
C_{\text {plant }}=C_{i n s / k W} P_{r, p v}
$$

The cost recovery factor can be computed using Equation (12) [23],

$$
C R F=\frac{i(1+i)^{n}}{(1+i)^{n}-1}
$$

where $i$ is the discount rate and $n$ is the system lifetime. The operation and maintenance cost can be computed by employing the escalation ratio in Equation (13) [23].

$$
C_{O M \_S}=\frac{C_{O M}}{i-\lambda_{o m}}\left[\frac{1-\left(1+\lambda_{o m}\right)^{n}}{(1+i)^{n}}\right]
$$

where $C_{O M} S$ is the operation and maintenance cost employing the escalation ratio, where $\lambda_{\text {om }}$ denotes the escalation ratio. As per Ref. [7], the accepted operation and maintenance cost is obtained $10 \mathrm{USD} / \mathrm{kW}$. 


\subsubsection{Model of Hydrogen Production Cost}

For a solar photovoltaic-hydrogen system, the $\mathrm{LCOH}$ can be determined based on the total annualized cost of the electrolyser, cost of electricity, and operation and maintenance cost of the electrolyser. The LCOH is computed as [23,24],

$$
L O C H=\frac{C_{E L} C R F_{E L}+C_{\text {electricity }}+C_{H S}+C_{O M_{-} E L}}{H_{P V, k g}}
$$

where $C_{E L}, C_{\text {electricty }}, C_{H S}$ and $C_{O M_{-} E L}$ are the capital cost of the electrolyser, electricity cost, hydrogen storage cost, and the operation and maintenance cost of the electrolyser and hydrogen storage system, respectively. $C R F_{E L}$ is the cost recovery factor of the electrolyser, and the cost recovery factor is determined using Equation (12). However, the lifetime of an electrolyser system is considered to be 20 years, which is different from the lifespan of the PV system, which is 25 years. The electrolyser capital cost is determined as [24]

$$
C_{E L}=P_{E L} C_{E L / k W}
$$

where $P_{E L}$ is the electrolyser capacity in $\mathrm{kW}$, and $C_{E L / k W}$ is the per $\mathrm{kW}$ cost of a specific electrolyser that is obtained from [13]. The required capacity of an electrolyser is found using Equation (16) as given in [50].

$$
P_{E L}=\frac{\text { Annual energy input to the electrolyser in } \mathrm{kWh}}{8760 U_{f}}
$$

where $U_{f}$ is the utilisation factor. The operation and maintenance cost of the electrolyser can be manifested as [35],

$$
C_{O M_{-} E L}=8760 m_{W} C_{W} U_{F}+0.03 C_{E L} C R F_{E L}
$$

where $m_{W}$ is the required water flow for the electrolyser in $\mathrm{m}^{3} / \mathrm{h}$, and $C_{W}$ is the cost of water in USD $/ \mathrm{m}^{3}$. The accepted operation and maintenance cost of a water electrolyser system is obtained from $[13,35]$, which is $5 \%$ of the annualized capital cost of the electrolyser. The hydrogen storage cost is taken $0.5 \mathrm{USD} / \mathrm{kg}$ [50].

\subsection{Implementation of the Methodology}

The process of evaluating hydrogen production potential and the unit cost of hydrogen involves energy output estimation from the renewable-based generation, quantifying the hydrogen production, calculating the cost of electricity from the renewable sources, and assessing the cost of hydrogen production. Figure 3 shows the implementation flow of the methodology described earlier. Site selection and renewable resource assessment are essential since hydrogen production depends on renewable sources, such as solar radiation. The temperature effect in PV power generation requires derating factors, which is critical for hot and humid locations. The large PV plant is selected to produce a large quantity of green hydrogen to reduce the hydrogen production cost. The energy output of the PV plant is determined that is used to calculate the LCOE, electrolyser size, and capacity factor. The capacity factor is used as a utilisation factor to determine the electrolyser size since hydrogen production is only based on solar power. Equation (7) uses the efficiency of the power electronic converter and the specific energy consumption by the electrolyser to calculate the per unit volume of hydrogen production. In order to be consistent with the literature and to present a better comparison, the per-unit hydrogen cost is converted into USD/ $\mathrm{kg}$ using Equation (8). The LCOE is calculated for the energy generated by the PV plant using the economic model and data related to financial analysis. This cost is used as the electricity cost to determine $\mathrm{LCOH}$. The $\mathrm{LCOH}$ also requires the size and utilisation factor of the electrolyser, which is determined using the energy available from the PV plant. Table 2 presents the data necessary to accomplish the implementation of the evaluation process. 


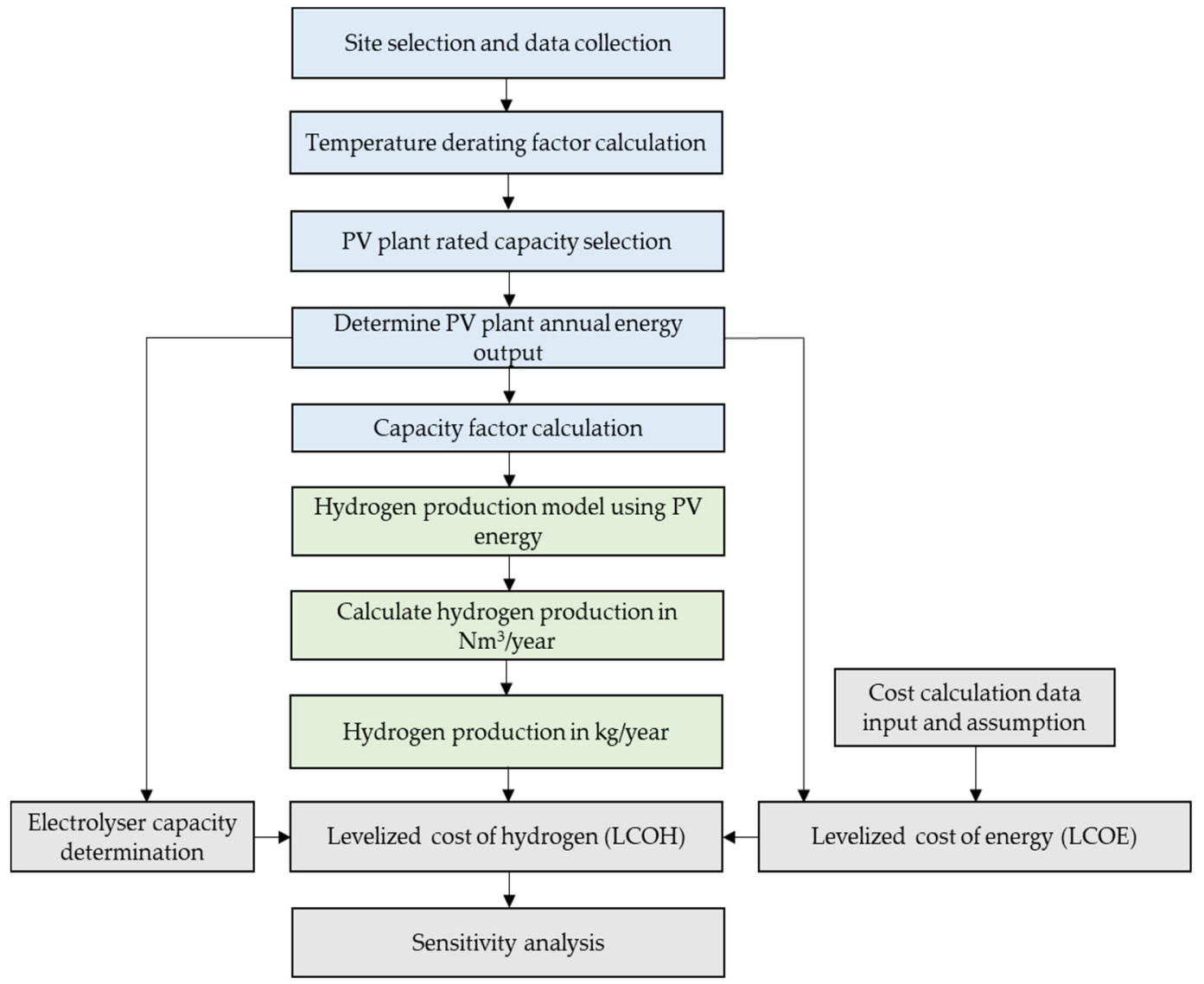

Figure 3. A process of evaluating hydrogen production potential and cost using renewable power generations.

Table 2. Data to implement evaluation process of hydrogen production potential and the LCOH.

\begin{tabular}{|c|c|c|}
\hline Parameter & Value & Reference/Data Obtained \\
\hline Solar radiation & Refer to Figure 4 & [51] \\
\hline Site temperature & Refer to Figure 5 & [51] \\
\hline $\begin{array}{l}\text { Derating factor due to system } \\
\text { components. PV module } \\
\text { nameplate DC rating, }\end{array}$ & & \\
\hline $\begin{array}{l}\text { transformer an inverter, } \\
\text { diodes and connections, AC } \\
\text { and DC wiring, soiling, } \\
\text { shading, system availability, } \\
\text { sun tracking, and age. }\end{array}$ & 0.7895 & {$[52]$} \\
\hline PV plant capacity & $2000 \mathrm{~kW}$ & Assumed \\
\hline Power converter efficiency & $95 \%$ & [35] \\
\hline Average power consumption & $4.53 \mathrm{kWh} / \mathrm{Nm}^{3}$ & [53] \\
\hline PV capital cost per $\mathrm{kW}$ & 996 USD & [7] \\
\hline Discount rate & $6.5 \%$ & [48] \\
\hline PV system lifetime & 25 years & [48] \\
\hline $\begin{array}{l}\text { Operation and maintenance } \\
\text { cost of PV plant in per } \mathrm{kW}\end{array}$ & 10 USD & [7] \\
\hline Electrolyser capital cost & $1010 \mathrm{USD} / \mathrm{kW}$ & [13] \\
\hline $\begin{array}{l}\text { Electrolyser's operation and } \\
\text { maintenance cost }\end{array}$ & $5 \%$ of the annualized capital cost & {$[13,35]$} \\
\hline Utilisation factor & $20 \%$ & [50] \\
\hline Hydrogen storage cost & $0.5 \mathrm{USD} / \mathrm{kg}$ & [50] \\
\hline
\end{tabular}




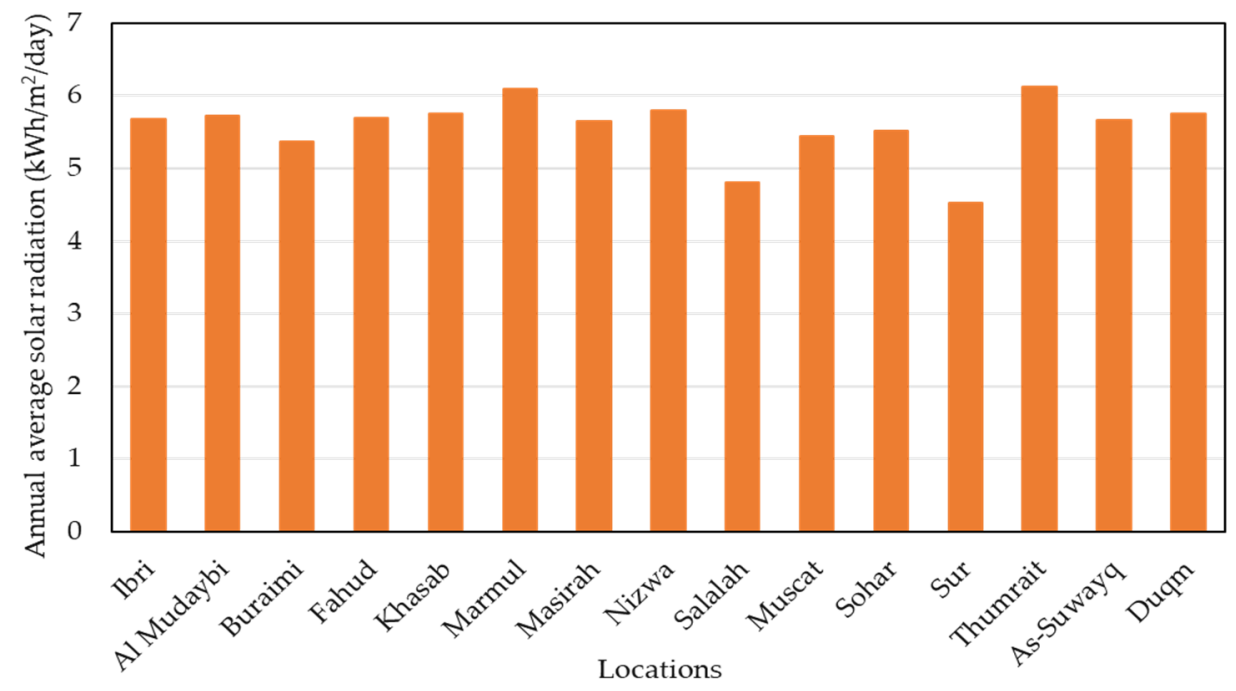

Figure 4. Annual average solar radiation in 15 different locations throughout the Sultanate of Oman.

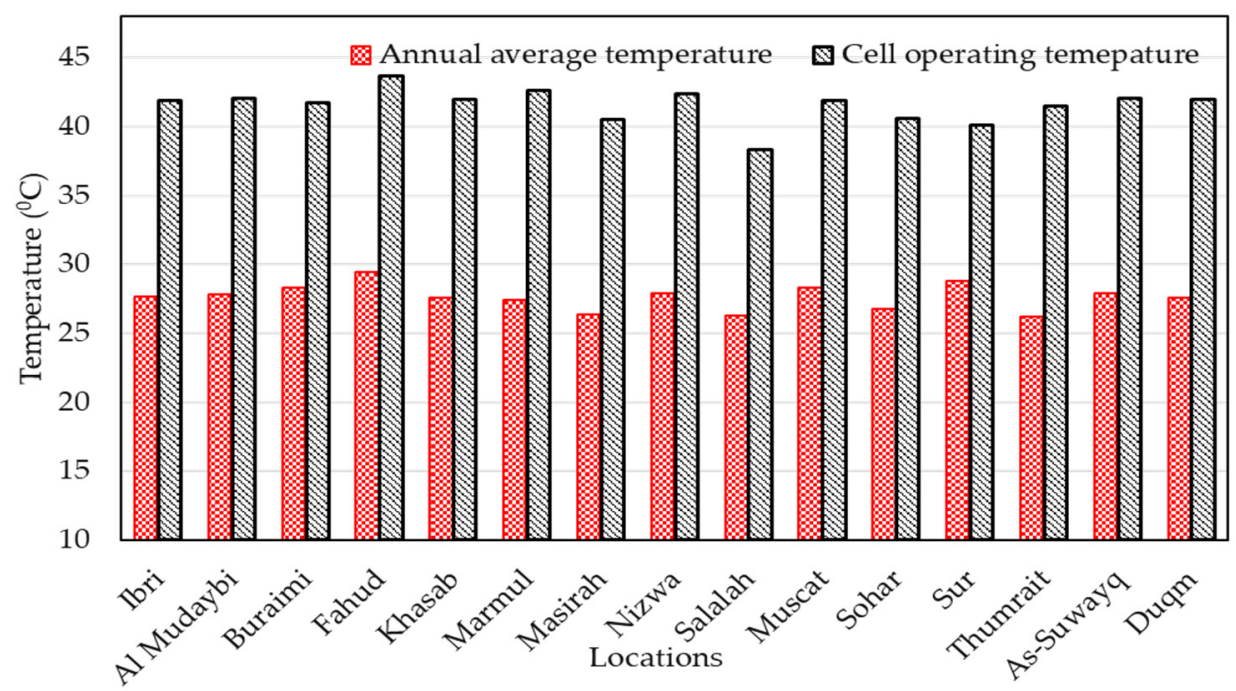

Figure 5. Annual average ambient temperature in 15 different locations and the photovoltaic cell operating temperature of these locations.

\section{Results and Discussion}

For the purpose of evaluating the hydrogen production potential using solar PV in the Sultanate of Oman, energy production from solar PV and hydrogen generation from solar energy is estimated for the selected locations in the Sultanate of Oman. The LCOE is assessed to determine the cost of electricity that is used by the electrolyser. With the concept of levelized cost, the $\mathrm{LCOH}$ is then calculated to investigate the economics of hydrogen production in the country. Finally, cost reduction scenarios and sensitivity analysis are carried out to reveal variables that significantly influence hydrogen production costs.

\subsection{Energy Output of the Solar PV Plant}

There are 15 different locations selected throughout the country. These locations have a solar radiation profile such that the hydrogen production potential of these locations can be compared with any other sites in the Sultanate. The selected areas are Ibri, Al Mudyib, Buraimi, Fahud, Khasab, Marmul, Masirah, Nizwa, Salalah, Muscat, Sohar, Sur, Thumrait, As-Suwayq, and Duqm. Figure 4 shows the annual average solar radiation for 15 different locations, and the range of solar radiation is from $4.53 \mathrm{kWh} / \mathrm{m}^{2} /$ day to $6.13 \mathrm{kWh} / \mathrm{m}^{2} /$ day. The highest solar radiation was found for Thumrait $\left(6.13 \mathrm{kWh} / \mathrm{m}^{2} /\right.$ day $)$ and Marmul 
(6.09 $\mathrm{kWh} / \mathrm{m}^{2} /$ day), whereas the lowest solar radiation was found in Salalah $\left(4.8 \mathrm{kWh} / \mathrm{m}^{2} /\right.$ day $)$ and Sur $\left(4.53 \mathrm{kWh} / \mathrm{m}^{2} /\right.$ day). The peak sun hour for these locations is calculated using the one-sun of insolation $\left(1 \mathrm{~kW} / \mathrm{m}^{2}\right)$ approach [52]. For example, Thumrait has solar radiation of $6.13 \mathrm{kWh} / \mathrm{m}^{2} /$ day. With the one-sun insolation approach, the peak sun hour for Thumrait was calculated as $6.13 \mathrm{~h}$. Table 3 shows the peak sun hour for the selected locations.

Table 3. Peak sun hour for 15 different locations in Oman.

\begin{tabular}{cc}
\hline Site Name & Peak Sun Hour (hours) \\
\hline Ibri & 5.68 \\
Al Mudaybi & 5.72 \\
Buraimi & 5.37 \\
Fahud & 5.69 \\
Khasab & 5.75 \\
Marmul & 6.09 \\
Masirah & 5.65 \\
Nizwa & 5.8 \\
Salalah & 4.8 \\
Muscat & 5.45 \\
Sohar & 5.51 \\
Sur & 4.53 \\
Thumrait & 6.13 \\
As-Suwayq & 5.66 \\
Duqm & 5.76 \\
\hline
\end{tabular}

Figure 5 captures the effect of ambient temperature on the PV cell operating temperature. The annual average temperature varies between $26.3^{\circ} \mathrm{C}$ and $29.46^{\circ} \mathrm{C}$. Fahud represents the highest temperature, $29.46^{\circ} \mathrm{C}$, and Salalah means the lowest temperature, which is $26.3^{\circ} \mathrm{C}$. Thumrait and Marmul possess the most increased solar radiation compared to Fahud; however, the temperatures in Thumrait and Marmul are lower compared to Fahud. On the other hand, Fahud has lower annual average solar radiation than in Tumrait and Marmul. The yearly average ambient temperature in Salalah $\left(26.3^{\circ} \mathrm{C}\right)$ and Thumrait $\left(26.2^{\circ} \mathrm{C}\right)$ are almost identical. However, the annual average solar radiations in Salalah and Thumrait are $4.8 \mathrm{kWh} / \mathrm{m}^{2} /$ day and $6.13 \mathrm{kWh} / \mathrm{m}^{2} /$ day, respectively. The higher ambient temperature results in a higher PV cell operating temperature that degrades the conversion efficiency of the PV system. Fahud has shown the highest PV cell operating temperature, whereas Salalah has revealed the lowest PV cell operating temperature. As a result, the highest percentage reduction in maximum power was noticed in the case of Fahud, which was about $7.1 \%$, as can be seen from Figure 6 . The minimum percentage reduction from the maximum output power was found in the case of Salalah, which was about $5.05 \%$. It can be attributed to the low ambient temperature in the Salalah. Regarding Thumrait and Marmul, Thumrait (6.27\%) has a lower percentage reduction in maximum output power than Marmul (6.7\%). The ambient temperature difference between Thumrait $\left(26.2{ }^{\circ} \mathrm{C}\right)$ and Marmul $\left(27.4{ }^{\circ} \mathrm{C}\right)$ is $1.2^{\circ} \mathrm{C}$, which causes a $0.43 \%$ reduction in the maximum power of the PV system. Ibri, Al Mudaybi, Khasab, Muscat, As-Suwayq, and Duqm have a similar temperature profile, which causes an almost identical amount of percentage reduction in maximum power. Nizwa has close characteristics to Marmul, while Buraimi and Thumrait have similar features. 


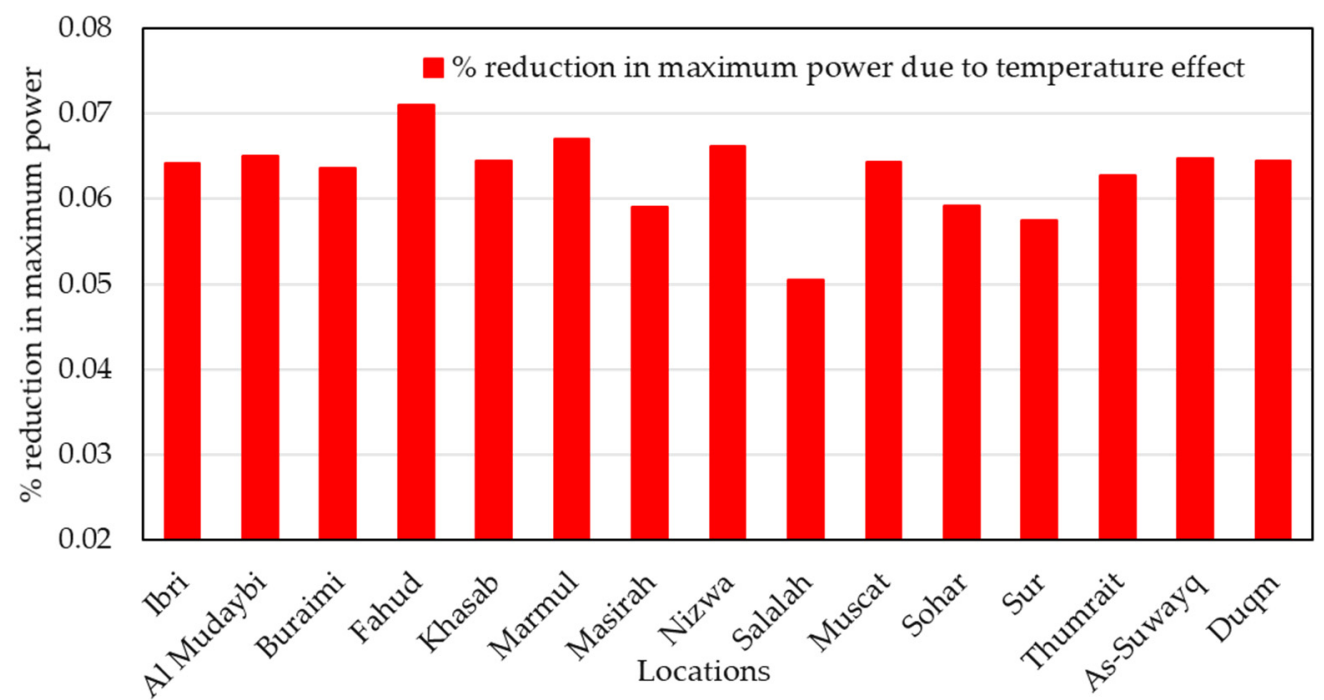

Figure 6. Percentage reduction in maximum power due to the temperature derating factor at 15 different locations.

A $2000 \mathrm{~kW}$ PV plant is considered for all the selected locations in the Sultanate of Oman to evaluate energy production. Figure 7 shows the annual energy production with and without considering the temperature effect for the chosen sites. The maximum annual energy production was found in Thumrait, whereas the yearly minimum energy generation was found in Sur. In Thumrait, the annual energy production with and without the temperature effect are $3311 \mathrm{MWh}$ and $3533 \mathrm{MWh}$, respectively. It indicates that about $6.27 \%$ of the yearly energy reduction in this location is due to temperature. In Sur, the yearly energy productions with and without the temperature effect are $2461 \mathrm{MWh}$ and $2611 \mathrm{MWh}$. This unveils that about $5.75 \%$ of the reduction in annual energy production for this location is due to temperature development. The temperature effect also reveals that Marmul can produce 3275 MWh of energy in a year, the second highest among all sites. Although Fahud has a slightly higher annual average solar radiation than Ibri, the annual energy production in Fahud (3046 MWh) is lower than Ibri (3064 MWh) because of the higher ambient temperature. This difference in annual energy production can be significant over the plant lifetime, which will impact the cost of electricity from the PV plant.

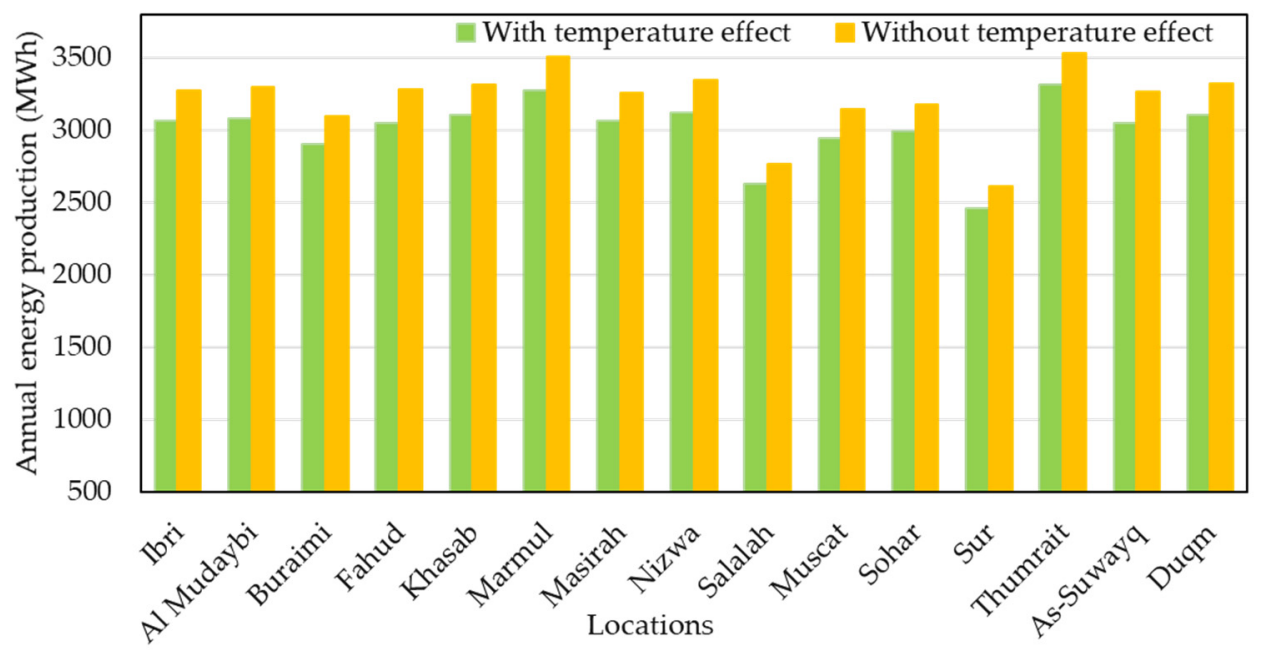

Figure 7. Annual energy production by a $2000 \mathrm{~kW}$ PV plant at 15 different locations in Oman.

For the purpose of estimating the utilisation factor required to determine the electrolyser size, the capacity factor of a $2000 \mathrm{~kW}$ PV plant is calculated for the selected locations. Figure 8 captures the capacity factors with and without considering the temperature effect 
for a $2000 \mathrm{~kW}$ PV plant for the designated areas. With the temperature effect, the study reveals that the capacity factor of the PV plant in Thumrait is 0.19 , while it is 0.14 in Sur. In Marmul, the capacity factor of the plant with temperature development was found to be 0.187 . With the temperature effect, the study also indicates that the capacity factor of the PV plant in Fahud is 0.165 , while it is 0.175 in Ibri. Thus, for all selected locations, the capacity factors of a $2000 \mathrm{~kW} \mathrm{PV}$ were found to be in a range of 0.14 to 0.19 . Such a range of capacity factors is identical to that reported in [54], indicating that the annual average capacity factor is 0.15 in the Muscat area, Oman. The current study found the capacity factor in the Muscat area to be 0.168 . Moreover, a typical PV plant's yearly average capacity factors in Brazil, Morocco, and India were reported as 0.192, 0.1484, and 0.1569, respectively [55-57].

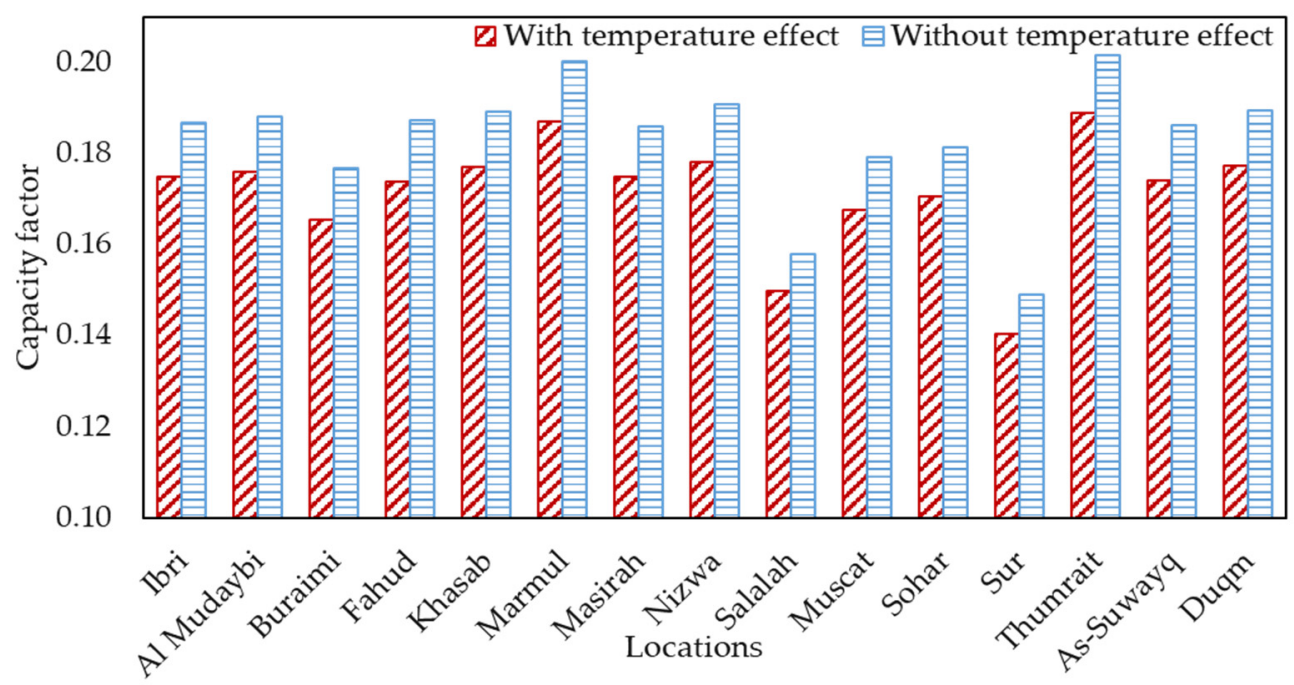

Figure 8. Capacity factors of a $2000 \mathrm{~kW}$ PV pant at 15 different locations in Oman with and without considering the temperature effect.

\subsection{Hydrogen Production Using Solar PV Power}

The solar PV plant's hydrogen production at the selected locations was computed using Equation (7). The energy output of the PV plant presented in Figure 7 is used as input to the electrolyser. Moreover, the hydrogen production calculation requires the efficiency of the power electronic converter and the amount of energy consumption by the selected electrolyser (PEM). The power electronic converter efficiency was considered to be $95 \%$ [35], and the electrolyser energy consumption was obtained at $4.53 \mathrm{kWh} / \mathrm{Nm}^{3}$ [53]. Figure 9 reveals the annual hydrogen production at 15 different locations in the Sultanate of Oman. The highest yearly hydrogen yield was found to be $694,377 \mathrm{Nm}^{3}(62,557 \mathrm{~kg})$ at Thumrait. Sur has revealed the hydrogen production of $516,050 \mathrm{Nm}^{3} /$ year $(46,491 \mathrm{~kg} /$ year), which is the lowest among the selected locations. Such a difference in hydrogen quantity comes from Thumrait and Sur's distinct solar radiation and temperature pattern. The Marmul site presents the second-highest hydrogen production potential, $686,769 \mathrm{Nm}^{3} /$ year $(61,871 \mathrm{~kg} /$ year). The prospect of hydrogen production in Fahud and Masirah was estimated at $57,558 \mathrm{~kg} /$ year and 57,892 kg/year, respectively. Regarding solar radiation, Fahud is expected to produce a higher amount of hydrogen per year; however, the study reveals a lower production of hydrogen in Fahud because of the elevated operating cell temperature of the PV system or ambient temperature. It indicates that the locations with high ambient temperature may lead to lower hydrogen production, hence less suitable to develop hydrogen production facilities. It is evident from Table 4 that Fahud is ranked 10th even though the solar radiation is higher than Masirah, which is ranked 7th. 


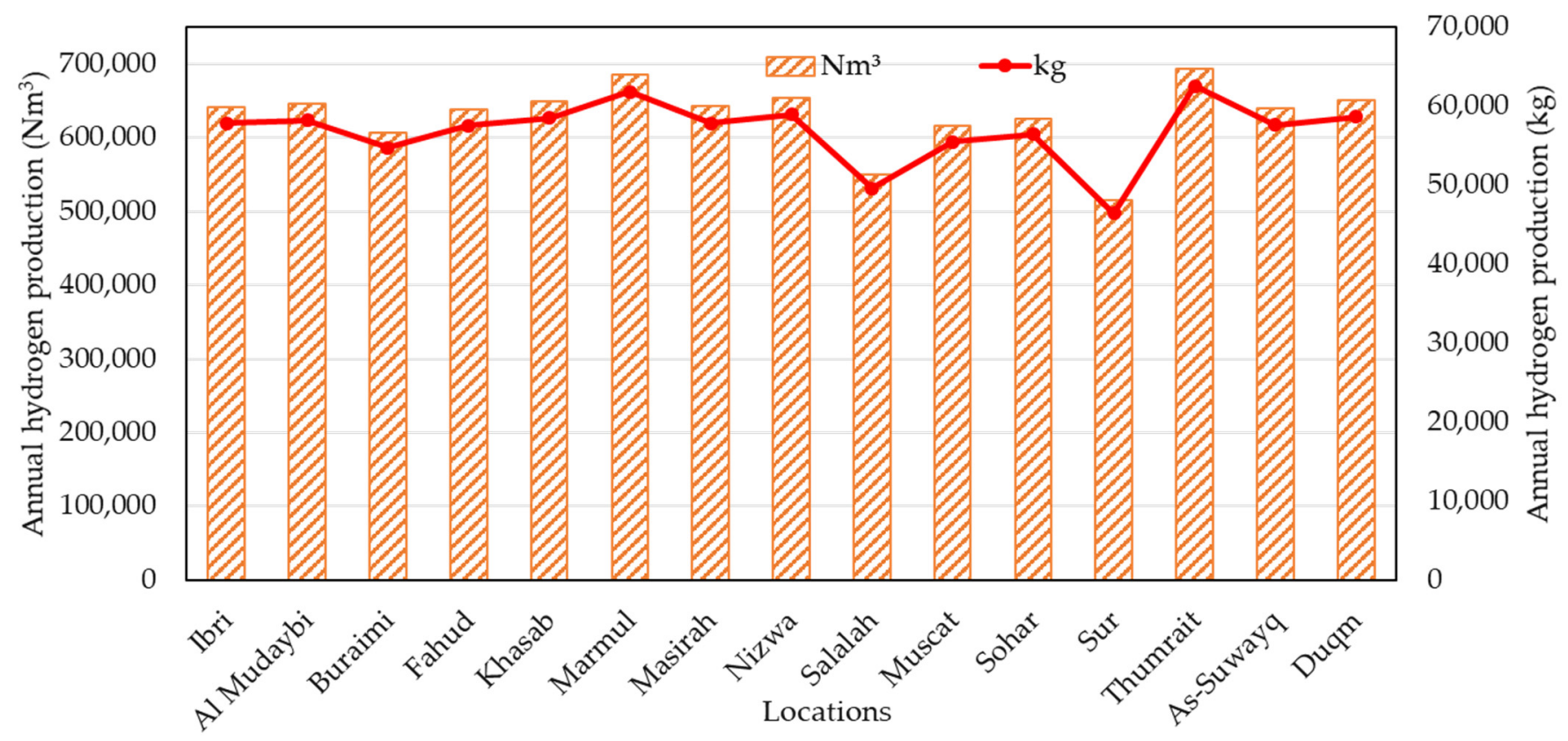

Figure 9. Annual hydrogen production at 15 different locations for a $2000 \mathrm{~kW}$ PV plant.

Table 4. Rank of potential locations based on yearly green hydrogen production by a $2000 \mathrm{~kW}$ solar PV plant in the Sultanate of Oman.

\begin{tabular}{|c|c|c|c|c|c|}
\hline Rank & Locations & $\begin{array}{l}\text { Solar Radiation } \\
\left(\mathrm{kW} / \mathrm{m}^{2} / \text { day }\right)\end{array}$ & $\begin{array}{c}\text { Ambient } \\
\text { Temperature }\left({ }^{\circ} \mathrm{C}\right)\end{array}$ & $\begin{array}{c}\text { Solar PV Energy } \\
\text { Production (MWh/year) }\end{array}$ & $\begin{array}{c}\text { Green Hydrogen } \\
\text { Production (kg/year) }\end{array}$ \\
\hline 1 & Thumrait & 6.13 & 26.2 & 3311 & 62,557 \\
\hline 2 & Marmul & 6.09 & 27.4 & 3275 & 61,871 \\
\hline 3 & Nizwa & 5.8 & 27.9 & 3122 & 58,979 \\
\hline 4 & Duqm & 5.76 & 27.56 & 3106 & 58,677 \\
\hline 5 & Khasab & 5.75 & 27.6 & 3100 & 58,572 \\
\hline 6 & Al Mudaybi & 5.72 & 27.8 & 3082 & 58,236 \\
\hline 7 & Masirah & 5.65 & 26.4 & 3064 & 57,892 \\
\hline 8 & Ibri & 5.68 & 27.7 & 3064 & 57,876 \\
\hline 9 & As-Suwayq & 5.66 & 27.9 & 3050 & 57,637 \\
\hline 10 & Fahud & 5.69 & 29.46 & 3046 & 57,558 \\
\hline 11 & Sohar & 5.51 & 26.8 & 2987 & 56,446 \\
\hline 12 & Muscat & 5.45 & 28.3 & 2939 & 55,527 \\
\hline 13 & Buraimi & 5.37 & 28.3 & 2898 & 54,756 \\
\hline 14 & Salalah & 4.8 & 26.3 & 2626 & 49,624 \\
\hline 15 & Sur & 4.53 & 28.8 & 2461 & 46,491 \\
\hline
\end{tabular}

Moreover, Masirah (57,892 kg/year), Ibri (57,876 kg/year), Al Mudaybi (58,236 kg/year), As-Suwayq $(57,637 \mathrm{~kg} /$ year), and Fahud (57,558 kg/year) have similar potential to produce green hydrogen. On the other hand, Nizwa (58,979 kg/year), Duqm (58,677 kg/year), and Khasab (58,572 kg/year) have identical prospects of producing green hydrogen. Table 4 presents the ranking of potential locations indicating the most to least suitable for green hydrogen production in the Sultanate of Oman. The position is ordered based on the merit of green hydrogen and solar PV energy production in a year. It shows that Sur is the least convenient location because it has the lowest annual average solar radiation and higher ambient temperature compared to the top-ranked sites.

The electrolyser capacity required to produce green hydrogen is determined using Equation (16). The electrolyser's energy for green hydrogen production is the same as the energy produced by the selected solar PV plant for all designated locations. Therefore, the utilisation factor is required to determine the capacity of the electrolyser. The utilisation 
factor is $20 \%$ since the hydrogen production facility solely depends on an intermittent solar PV plant. Figure 10 presents the electrolyser capacity required for the selected locations. The largest capacity electrolyser was $1890 \mathrm{~kW}$, which was necessary for the top-ranked site, Thumrait. On the other hand, the smallest capacity electrolyser was $1404 \mathrm{~kW}$, needed for the lowest-ranked location, Sur. The electrolyser capacity rating is used for computing the capital cost of the electrolyser.

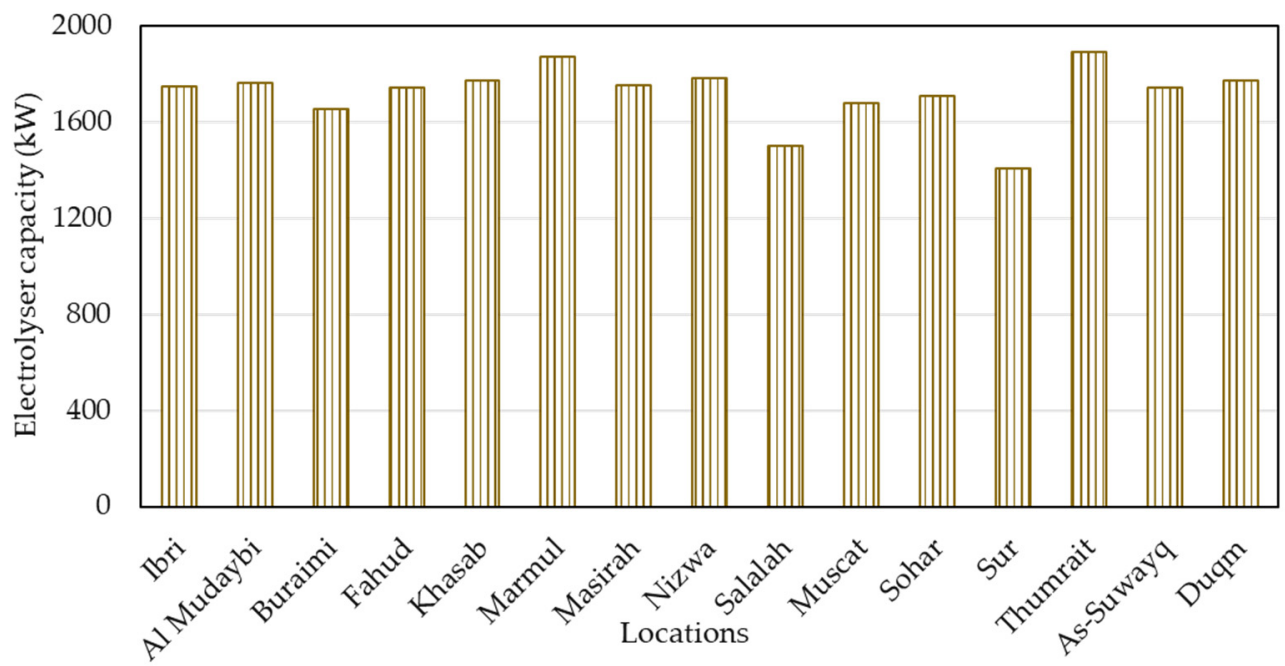

Figure 10. Electrolyser capacity required for hydrogen production at 15 different locations.

\subsection{Economic Analysis}

To calculate the production cost of hydrogen for the selected locations, the cost of energy using a solar PV plant in those locations is determined first. Then, this electricity cost is input to compute the LCOH hydrogen. In calculating the LCOE, the capital cost of the PV system is determined based on the cost of per $\mathrm{kW}$ installed capacity, as presented in Table 2. In addition, the discount rate, PV plant lifetime, and operation and maintenance cost are also outlined in Table 2. Figure 11 explains the LCOE if a $2000 \mathrm{~kW}$ PV plant is located in the selected sites. The LCOE was found to be the lowest in Thumrait, and it was $0.0554 \mathrm{USD} / \mathrm{kWh}$. The LCOE in Marmul was $0.0560 \mathrm{USD} / \mathrm{kWh}$, which is the following economic site. It can be attributed to the fact that these sites have the best solar radiation and moderate temperature profile. The study also indicates that Sur and Salalah are the least suitable sites, revealing an LCOE of about $0.0745 \mathrm{USD} / \mathrm{kWh}$ and $0.0698 \mathrm{USD} / \mathrm{kWh}$, respectively. It can be associated that these two locations have the lowest solar radiation, whereas Sur has the higher temperature profile; however, Salalah has a moderate temperature profile. The LCOEs for the PV plants in Nizwa, Duqm, Khasab, Al Mudaybi, Masirah, Ibri, As-Suwayq, and Fahud are 0.0587, 0.0590, 0.0591, 0.0595, 0.0598, 0.0598, 0.0601, and 0.0602 USD/kWh, respectively. Masirah and Ibri indicate an identical LCOE, although the solar radiation in Ibri is higher. However, Ibri is the hotter site compared to Masirah. 


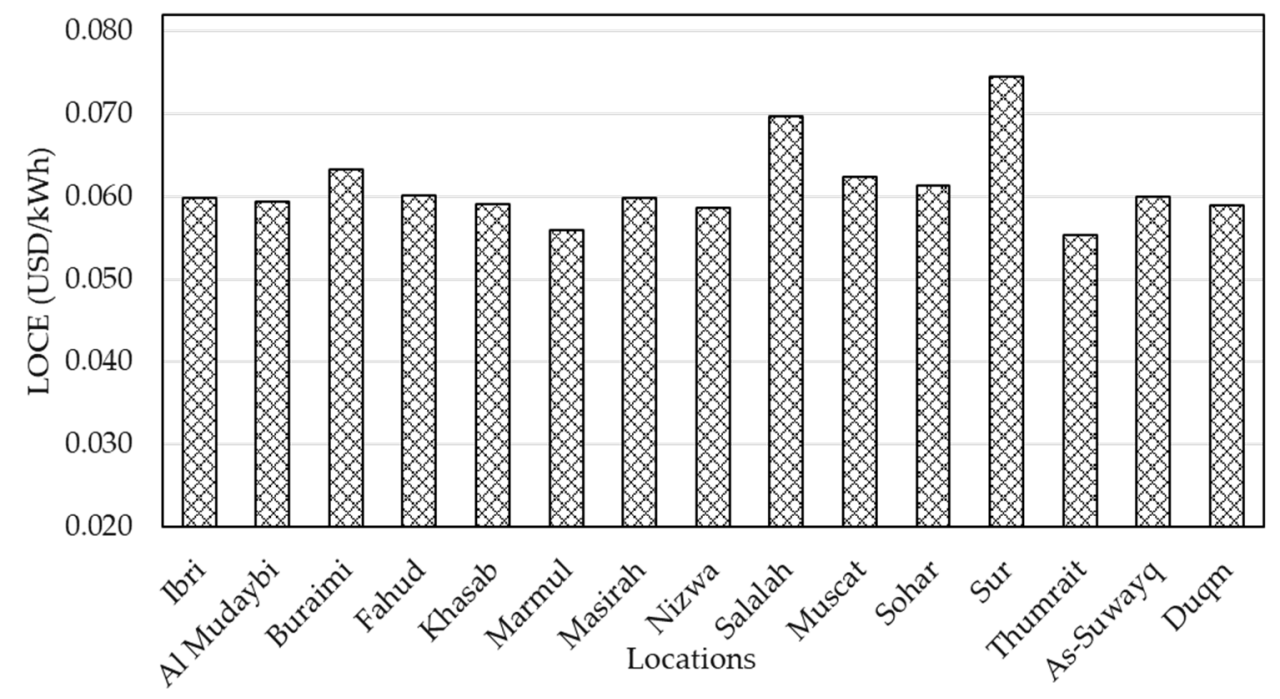

Figure 11. Levelized cost of energy produced from the solar PV plant at 15 different locations.

Further, some of the sites, namely Nizwa, Duqm, and Khasab, reveal a slight difference in LCOE; however, this can influence the total revenue of the project owner in consideration of the entire project lifetime. The LCOEs for the solar PV plants in Sohar, Muscat, and Buraimi are $0.0614,0.0624$, and $0.0632 \mathrm{USD} / \mathrm{kWh}$. Therefore, the range of LCOE for the selected PV plant in the designated locations is 0.0554 to $0.0745 \mathrm{USD} / \mathrm{kWh}$. This range of the LCOE is consistent with the LCOE for solar photovoltaic technology, as indicated in [7].

For evaluating the production cost of hydrogen for the selected locations, the cost of energy consumed by the electrolyser is obtained as per the LOCE determined in the preceding section. In calculating the $\mathrm{LCOH}$, the capital cost of the water electrolyser is obtained as the per $\mathrm{kW}$ capacity cost that includes power supply and installation costs, as given in Table 2. In addition, the discount rate, electrolyser lifetime, and costs of operation and maintenance are also presented in Table 2. Figure 12 unveils the cost of hydrogen production using a $2000 \mathrm{~kW}$ solar PV plant for the selected location in the Sultanate of Oman. The LCOH in Thumrait was found to be the lowest, and it was $6.31 \mathrm{USD} / \mathrm{kg}$. The $\mathrm{LCOH}$ was found to be $6.34 \mathrm{USD} / \mathrm{kg}$ in Marmul, the second-best economic site. It can be connected to the lowest-cost electricity availability in Thumrait and Marmul, which comes from the rich solar radiation and moderate temperature profile. The investigation also shows that Sur and Salalah are the least suitable sites, revealing an LCOH of about 7.32 USD/kg and 7.07 USD/kg, respectively. It can be understood that Sur and Salalah require a high cost to generate solar PV-based electricity, which comes from the low-level solar radiation profile. In addition, Sur has a higher temperature profile; however, Salalah has a moderate temperature profile.

The LCOHs for the solar PV-based systems in Nizwa, Duqm, Khasab, Al Mudaybi, Masirah, Ibri, As-Suwayq, and Fahud are 6.49, 6.50, 6.51, 6.53, 6.55, 6.55, 6.56, and $6.56 \mathrm{USD} / \mathrm{kg}$, respectively. Masirah and Ibri indicate an identical LCOH, although the solar radiation in Ibri is higher. However, Ibri is the hotter site compared to the Masirah. Moreover, some of the sites, namely Nizwa, Duqm, and Khasab, reveal a slight difference in $\mathrm{LCOH}$; however, this can influence the total revenue of the project owner in consideration of the entire project lifetime. The LCOHs for the solar PV-based systems in Sohar, Muscat, and Buraimi are $6.63,6.68$, and $6.73 \mathrm{USD} / \mathrm{kg}$. Therefore, this research finds the range of LCOH for the designated locations to be from 6.31 to $7.32 \mathrm{USD} / \mathrm{kg}$ with the selected solar PV-based hydrogen production system. Such a range of the LCOH is lower than reported in [13], indicating that the $\mathrm{LCOH}$ at a $25 \%$ utilisation factor is about $12.12 \mathrm{USD} / \mathrm{kg}$ $(\approx 10 € / \mathrm{kg}$ ). The current study has observed the range of the LCOH 6.31 to $7.32 \mathrm{USD} / \mathrm{kg}$ for a $20 \%$ utilisation factor. Moreover, the $\mathrm{LCOH}$ was found in recent studies, such as 6.02 USD/kg [50], 8.14 USD/kg [39], 11.09 USD/kg [38], and 10.08 USD/kg [35]. The low 
value of the $\mathrm{LCOH}$ was reported at $6.02 \mathrm{USD} / \mathrm{kg}$ [50], which has used a utilisation factor of $85 \%$. It is worth mentioning that the LCOH found in this study (considering the low utilisation factor) is almost identical to those obtained at the higher utilisation factor. This can be attributed to the high solar radiation available in the sites.

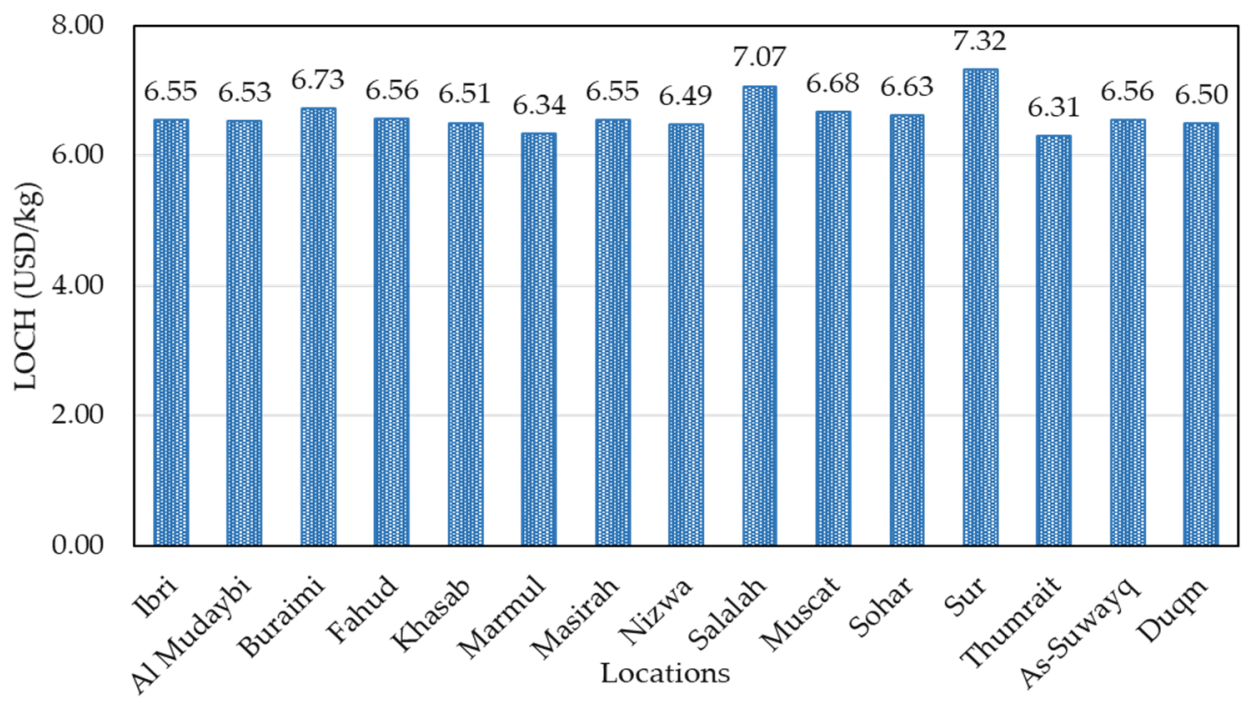

Figure 12. Cost of hydrogen production using the solar PV plant at 15 different locations.

\subsection{Sensitivity Analysis}

For the purpose of identifying significantly influential variables to hydrogen production cost, a sensitivity analysis is performed. This analysis considers hydrogen production cost at Thumrait as the base case cost, which is $6.31 \mathrm{USD} / \mathrm{kg}$. Thumrait has been shown as the best potential location for producing hydrogen in the Sultanate of Oman. In the base case, $\mathrm{LCOH}$ computation, the inputs to the hydrogen production cost, such as capital cost of the electrolyser, electricity cost, and utilisation factor, were considered as $1010 \mathrm{USD} / \mathrm{kW}$, $0.0554 \mathrm{USD} / \mathrm{kWh}$ (or $55.4 \mathrm{USD} / \mathrm{MWh}$ ), and $20 \%$ utilisation factor. These inputs are modified by a $10 \%$ increase and decrease in a range of $-50 \%$ to $50 \%$. Figure 13 captures the sensitivity results of green hydrogen production costs for the best suitable location, Thumrait. It indicates that the electricity cost is the primary influential cost input to the $\mathrm{LCOH}$. In addition, the capital cost is the second most significant factor that can change the $\mathrm{LCOH}$. With the higher utilisation factor, the $\mathrm{LCOH}$ can reduce as can be seen from Figure 13. However, electricity and capital costs are the most influential variables contributing to cost-effective hydrogen production in Oman.

Furthermore, three cost reduction cases were analysed for 20 years to estimate the production cost of hydrogen in the future. The cost reduction cases include: (1) Reducing the electrolyser capital cost only; (2) reducing the electricity cost only; (3) reducing both the electrolyser capital cost and electricity cost. This analysis applies a 3\% capital cost reduction of the electrolyser and a $4 \%$ electricity cost reduction $[4,50]$ yearly. Figure 14 reveals the hydrogen production cost profile over 20 years for three different cost reduction scenarios. With the electrolyser capital cost reduction only, the $\mathrm{LCOH}$ can be reduced from 6.31 to $5.05 \mathrm{USD} / \mathrm{kg}$, which is about a $19.96 \%$ cost reduction at the end of 20 years. With the electricity cost reduction only, the $\mathrm{LCOH}$ can decrease from 6.31 to $4.68 \mathrm{USD} / \mathrm{kg}$, which is about a $25.58 \%$ cost reduction at the end of 20 years. For both the electrolyser capital cost and electricity cost decrease, the LCOH shows a significant decline, from 6.31 to $3.41 \mathrm{USD} / \mathrm{kg}$, and it is about a $45.96 \%$ downturn in the $\mathrm{LCOH}$. 


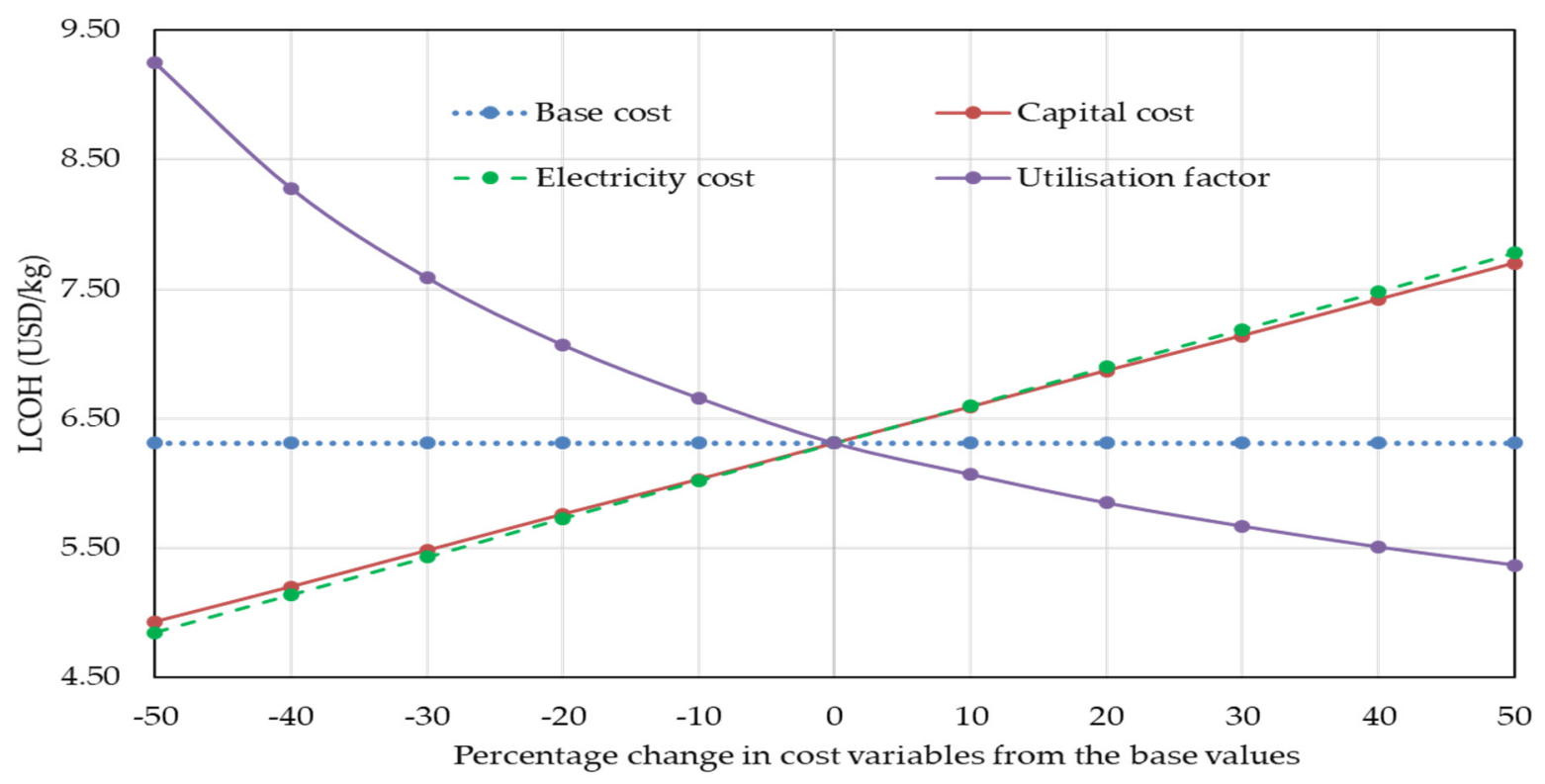

Figure 13. Sensitivity of the hydrogen production cost with a change in cost variables from $-50 \%$ to $50 \%$.

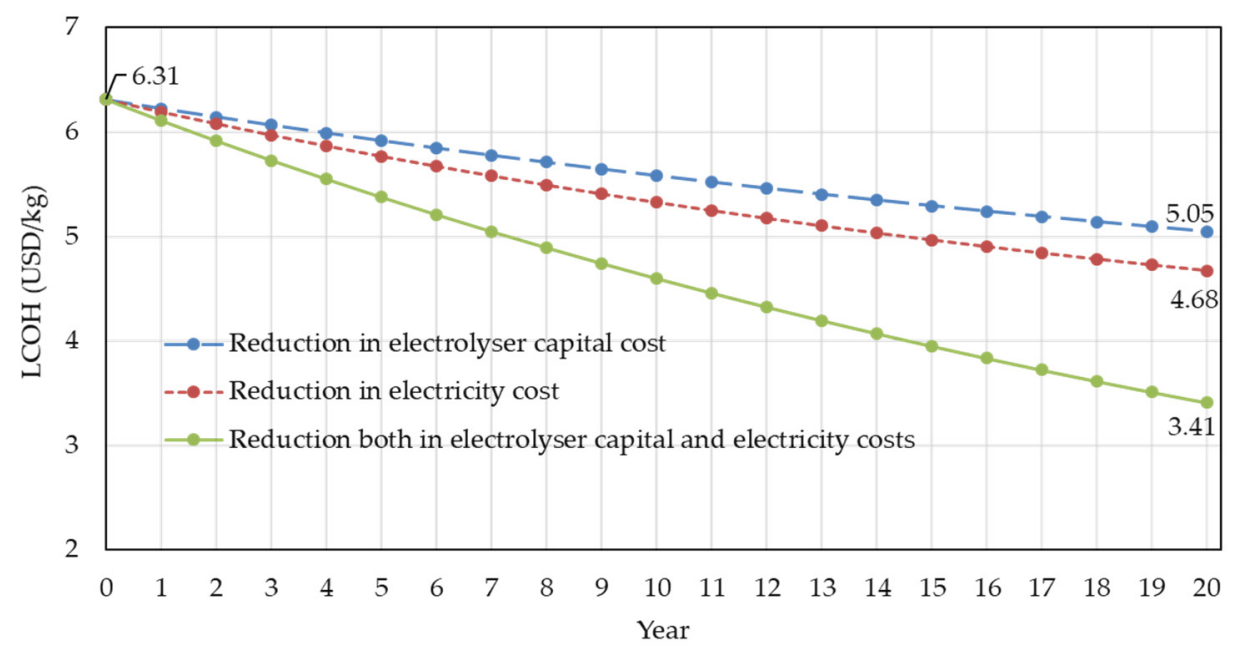

Figure 14. Hydrogen production cost profile over 20 years for three different cost reduction cases.

\subsection{Technology Adoption Factors and Environmental Impact}

It is worth mentioning that this study focused on PEM electrolyser technology-based hydrogen production. The cost of the technology is one of the significant factors to consider when adopting technology. The cost reduction of PEM technology is substantial with the system scale-up [58]. The cost reduction rate of the PEM electrolyser is faster than the other technologies. The flexibility and shorter response time of the PEM electrolyser are other driving factors of this technology. They allow supplying hydrogen to various clients, i.e., industry, mobility, or injection into the gas network, simultaneously [13]. These features can enhance overall hydrogen production economics by earning revenues from multiple stakeholders and help in compensating the higher capital cost of PEM compared to alkaline electrolysers. Moreover, the PEM electrolyser is the most energy-efficient and clean technology, as indicated in [59].

Solar photovoltaic-to-hydrogen production can reduce greenhouse gas emissions significantly. The greenhouse gas emission reduction for the study system in this research is estimated based on the emission factors given in [60]. It reveals that about 2346 metric tons of greenhouse gas emissions can be reduced per annum upon operating a system presented in this study. 


\section{Conclusions}

This paper has presented a techno-economic analysis of producing green hydrogen using solar photovoltaic power in the Sultanate of Oman. The analysis process includes energy production evaluation of a photovoltaic power plant, hydrogen generation quantification, and assessing electricity cost, green hydrogen production cost, and environmental impact. The study is conducted for 15 different locations in Oman with a large-size $(2000 \mathrm{~kW})$ photovoltaic plant. The inclusion of intermittent solar radiation and varying temperature conditions into the energy production evaluation process of the solar photovoltaic plant ensures accurate energy determination. Such accuracy is confirmed by comparing the photovoltaic plant capacity factor found in this study with those available in the literature. The produced hydrogen quantification process has used this calculated energy amount instead of the estimated energy based on assuming a capacity factor.

Thumrait has been revealed as the most suitable green hydrogen generation location, producing $62,557 \mathrm{~kg} /$ year for the selected photovoltaic power plant. On the contrary, Sur has been unveiled as the least qualified site of green hydrogen production with $46,491 \mathrm{~kg}$ /year for the same photovoltaic power plant. Based on the amount of annual hydrogen production, a ranking of suitable locations is provided in this study. It is indicated that a location with higher solar radiation may not produce more green hydrogen fuel because of the higher ambient temperature in the site that causes a decline in the plant energy production, hence, hydrogen production. In addition, factors that may influence hydrogen production, cost, and emission are dust, cloud, shadow, and solar eclipse, which directly affect solar power production.

Furthermore, the analysis process has evaluated the cost of energy production from a solar photovoltaic plant instead of assuming the electricity cost for the electrolyser. The levelized cost of energy from the photovoltaic plant has been found to be 0.0554 to $0.0745 \mathrm{USD} / \mathrm{kWh}$. The economic analysis of hydrogen production has utilised this electricity cost to determine the production cost of green hydrogen based on solar photovoltaic power. It was shown that the hydrogen production cost for the selected locations in Oman is in the range of 6.31 to $7.32 \mathrm{USD} / \mathrm{kg}$. The obtained range of hydrogen production costs shows consistency with the hydrogen production costs reported in the other studies. Thumrait has the highest potential of producing green hydrogen fuel with a cost of $6.31 \mathrm{USD} / \mathrm{kg}$, and Sur has the least potential with a cost of $7.32 \mathrm{USD} / \mathrm{kg}$. Similar solar radiation and temperature profiles of any other candidate locations in Oman are comparable with the presented sites in this study to find their potentiality of producing green hydrogen. Otherwise, the illustrated analysis process can be applied to identify the potentiality of any other candidate locations in Oman and beyond, given that the source of electricity is based on a solar photovoltaic plant.

In addition, a sensitivity analysis has been performed on hydrogen production cost as the last step of the analysis process in this study. The sensitivity analysis has revealed that the electricity cost has a notable influence in calculating the production cost of hydrogen followed by the capital cost of the electrolyser. A consolidated yearly cost decline rate of $3 \%$ in capital cost and $4 \%$ in electricity cost unveils a hydrogen production cost decline of $45.96 \%$ in 20 years. The fruitful cognisance obtained through this study provides an assessment process for researchers, industry, energy stakeholders, and energy policymakers on solar photovoltaic-to-hydrogen potential, cost of hydrogen production, and cost variables to identify critical ones for a hot and humid condition, like the Sultanate of Oman.

The life cycle costing approach is a holistic and comprehensive method utilised to evaluate the economics of hydrogen production in this study. However, the methodology uses future estimated data since the electrolysis-based hydrogen production technology is yet to be in the expansion stage. As a result, uncertain assumptions on some of the fundamental cost data were unavoidable.

Only a solar-based hydrogen production system is limited to a low utilisation factor, which requires an increased size of the electrolyser. A hydrogen production system may need to be designed with a higher utilisation factor of the electrolyser; thus, the size and 
cost of the hydrogen production system can be reduced, which will be further investigated in general and specifically in Omani conditions.

Funding: This research received no external funding.

Institutional Review Board Statement: Not applicable.

Informed Consent Statement: Not applicable.

Data Availability Statement: Not applicable.

Conflicts of Interest: The author declares no conflict of interest.

\section{References}

1. Renewable Capacity Statistics 2021. Available online: https://www.irena.org/publications/2021/March/Renewable-CapacityStatistics-2021 (accessed on 4 June 2021).

2. Behabtu, H.A.; Messagie, M.; Coosemans, T.; Berecibar, M.; Anlay Fante, K.; Kebede, A.A.; Mierlo, J.V. A Review of Energy Storage Technologies' Application Potentials in Renewable Energy Sources Grid Integration. Sustainability 2020, 12, 10511. [CrossRef]

3. Hydrogen Insights: A Perspective on Hydrogen Investment, Market Development and Cost Competitiveness February 2021. Available online: https://hydrogencouncil.com/wp-content/uploads/2021/02/Hydrogen-Insights-2021-Report.pdf (accessed on 5 June 2021).

4. Path to Hydrogen Competitiveness: A Cost Perspective, 20 January 2020. Available online: https://hydrogencouncil.com/en/ path-to-hydrogen-competitiveness-a-cost-perspective (accessed on 5 June 2021).

5. Hossain, E.; Petrovic, S. Renewable Energy Crash Course: A Concise Introduction, 1st ed.; Springer International Publishing: Basel, Switzerland, 2021.

6. Qazi, A.; Hussain, F.; Rahim, N.A.; Hardaker, G.; Alghazzawi, D.; Shaban, K.; Haruna, K. Towards Sustainable Energy: A Systematic Review of Renewable Energy Sources, Technologies, and Public Opinions. IEEE Access 2019, 7, 63837-63851. [CrossRef]

7. IRENA (2020), Renewable Power Generation Costs in 2019, International Renewable Energy Agency, Abu Dhabi. Available online: https:/ / www.irena.org/publications/2020/Jun/Renewable-Power-Costs-in-2019 (accessed on 27 August 2020).

8. Al-Badi, A.H.; Malik, A.; Gastli, A. Sustainable energy usage in Oman-opportunities and Barriers. Renew. Sustain. Energy Rev. 2011, 15, 3780-3788. [CrossRef]

9. Ahshan, R.; Shafiq, M.; Hosseinzadeh, N.; Al-Badi, A. Distributed wind systems for moderate wind speed sites. In Proceedings of the 2018 5th International Conference on Renewable Energy: Generation and Applications (ICREGA), Al Ain, United Arab Emirates, 25-28 February 2018; Institute of Electrical and Electronics Engineers (IEEE), 2018; pp. 1-5.

10. Ahshan, R.; Al-Badi, A.; Hosseinzadeh, N.; Shafiq, M. Small Wind Turbine Systems for Application in Oman. In Proceedings of the 2018 5th International Conference on Electric Power and Energy Conversion Systems (EPECS), Kitakyushu, Japan, 23-25 April 2018; Institute of Electrical and Electronics Engineers (IEEE), 2018; pp. 1-6.

11. Gastli, A.; Charabi, Y. Solar electricity prospects in Oman using GIS-based solar radiation maps. Renew. Sustain. Energy Rev. 2010, 14, 790-797. [CrossRef]

12. OPWP's 7 Year Statement 2018-2024, Issue-12. 2018. Available online: https://www.omanpwp.om/PDF/7\%20Year\%20 Statement\%20Issue\%2012\%202018-2024.pdf (accessed on 24 May 2021).

13. Hydrogen from Renewable Power: Technology Outlook for the Energy Transition. Available online: https://www.irena.org/ media/Files/IRENA/Agency/Publication/2018/Sep/IRENA_Hydrogen_from_renewable_power_2018.pdf (accessed on 5 June 2021).

14. Van de Graaf, T.; Overland, I.; Scholten, D.; Westphal, K. The new oil? The geopolitics and international governance of hydrogen. Energy Res. Soc. Sci. 2020, 70, 101667. [CrossRef]

15. Noussan, M.; Raimondi, P.; Scita, R.; Hafner, M. The Role of Green and Blue Hydrogen in the Energy Transition-A Technological and Geopolitical Perspective. Sustainability 2020, 13, 298. [CrossRef]

16. Sun, P.; Elgowainy, A. Updates of Hydrogen Production from SMR Process in GREET ${ }^{\circledR}$ 2019. Argonne National Laboratory. 2019. Available online: https:/ / greet.es.anl.gov/publication-smr_h2_2019 (accessed on 9 August 2021).

17. Soltani, R.; Rosen, M.; Dincer, I. Assessment of $\mathrm{CO}_{2}$ capture options from various points in steam methane reforming for hydrogen production. Int. J. Hydrogen Energy 2014, 39, 20266-20275. [CrossRef]

18. Khan, M.H.A.; Daiyan, R.; Neal, P.; Haque, N.; MacGill, I.; Amal, R. A framework for assessing economics of blue hydrogen production from steam methane reforming using carbon capture storage \& utilization. Int. J. Hydrogen Energy 2021, 46, 2268522706.

19. Blue Hydrogen Production Should Be Restricted due to Associated Emissions and High Costs. Available online: https: / / www.rechargenews.com/energy-transition/blue-hydrogen-production-should-be-restricted-due-to-associatedemissions-and-high-costs /2-1-990584 (accessed on 9 August 2021).

20. Yodwong, B.; Guilbert, D.; Phattanasak, M.; Kaewmanee, W.; Hinaje, M.; Vitale, G. AC-DC Converters for Electrolyzer Applications: State of the Art and Future Challenges. Electronics 2020, 9, 912. [CrossRef] 
21. Lettenmeier, P. Efficiency-Electrolysis: White Paper. 2019. Available online: https:/ /assets.new.siemens.com/siemens/assets / api/uuid:139de890-44e1-453b-8176-c3d45c905178/white-paper-efficiency-en.pdf (accessed on 7 June 2021).

22. Mohammadi, A.; Mehrpooya, M. A comprehensive review on coupling different types of electrolyzer to renewable energy sources. Energy 2018, 158, 632-655. [CrossRef]

23. Genç, G.; Çelik, M.; Serdar Genç, M. Cost analysis of wind-electrolyzer-fuel cell system for energy demand in Pnarbaş-Kayseri. Int. J. Hydrogen Energy 2012, 37, 12158-12166. [CrossRef]

24. Genç, M.S.; Çelik, M.; Karasu, I. A review on wind energy and wind-hydrogen production in Turkey: A case study of hydrogen production via electrolysis system supplied by wind energy conversion system in Central Anatolian Turkey. Renew. Sustain. Energy Rev. 2012, 16, 6631-6646. [CrossRef]

25. Loisel, R.; Baranger, L.; Chemouri, N.; Spinu, S.; Pardo, S. Economic evaluation of hybrid off-shore wind power and hydrogen storage system. Int. J. Hydrogen Energy 2015, 40, 6727-6739. [CrossRef]

26. Manage, M.; Hodgson, D.; Milligan, N.; Simons, S.; Brett, D. A techno-economic appraisal of hydrogen generation and the case for solid oxide electrolyser cells. Int. J. Hydrogen Energy 2011, 36, 5782-5796. [CrossRef]

27. Power2Hydrogen: Electrolysis, Silyzer. 2019. Available online: https://assets.new.siemens.com/siemens/assets./api/uuid: 33ef5476-2a47-4421-802be48564d210ac/version:1595233590/2019-10-23-power2x-silyzer-gernot-schneider.pdf (accessed on 7 June 2021).

28. Wilberforce, T.; Olabi, A.G. Performance Prediction of Proton Exchange Membrane Fuel Cells (PEMFC) Using Adaptive Neuro Inference System (ANFIS). Sustaininability 2020, 12, 4952. [CrossRef]

29. Pascuzzi, S.; Anifantis, A.S.; Blanco, I.; Mugnozza, G.S. Electrolyzer Performance Analysis of an Integrated Hydrogen Power System for Greenhouse Heating. A Case Study. Sustaininability 2016, 8, 629. [CrossRef]

30. Viktorsson, L.; Heinonen, J.T.; Skulason, J.B.; Unnthorsson, R. A Step towards the Hydrogen Economy-A Life Cycle Cost Analysis of A Hydrogen Refueling Station. Energies 2017, 10, 763. [CrossRef]

31. Aiche-Hamane, L.; Belhamel, M.; Benyoucef, B.; Hamane, M. Feasibility study of hydrogen production from wind power in the region of Ghardaia. Int. J. Hydrogen Energy 2009, 34, 4947-4952. [CrossRef]

32. Ulleberg, Ø.; Nakken, T.; Eté, A. The wind/hydrogen demonstration system at Utsira in Norway: Evaluation of system performance using operational data and updated hydrogen energy system modeling tools. Int. J. Hydrogen Energy 2010, 35, 1841-1852. [CrossRef]

33. Geer, T.; Manwell, J.F.; McGowan, G. A Feasibility Study of a Wind/Hydrogen System for Martha's Vineyard, Massachusetts. In Proceedings of the American Wind Energy Association Windpower 2005 Conference, Denver, CO, USA, 15-16 May 2005.

34. Olateju, B.; Kumar, A. Hydrogen production from wind energy in Western Canada for upgrading bitumen from oil sands. Energy 2011, 36, 6326-6339. [CrossRef]

35. Nadaleti, W.C.; dos Santos, G.B.; Lourenço, V. The potential and economic viability of hydrogen production from the use of hydroelectric and wind farms surplus energy in Brazil: A national and pioneering analysis. Int. J. Hydrogen Energy 2020, 45, 1373-1384. [CrossRef]

36. Menanteau, P.; Quéméré, M.-M.; Le Duigou, A.; Le Bastard, S. An economic analysis of the production of hydrogen from wind-generated electricity for use in transport applications. Energy Policy 2011, 39, 2957-2965. [CrossRef]

37. Olateju, B.; Kumar, A.; Secanell, M. A techno-economic assessment of large scale wind-hydrogen production with energy storage in Western Canada. Int. J. Hydrogen Energy 2016, 41, 8755-8776. [CrossRef]

38. Mastropasqua, L.; Pecenati, I.; Giostri, A.; Campanari, S. Solar hydrogen production: Techno-economic analysis of a parabolic dish-supported high-temperature electrolysis system. Appl. Energy 2020, 261, 114392. [CrossRef]

39. Moser, M.; Pecchi, M.; Fend, T. Techno-Economic Assessment of Solar Hydrogen Production by Means of Thermo-Chemical Cycles. Energies 2019, 12, 352. [CrossRef]

40. Derbal-Mokrane, H.; Benzaoui, A.; M’Raoui, A.; Belhamel, M. Feasibility study for hydrogen production using hybrid solar power in Algeria. Int. J. Hydrogen Energy 2011, 36, 4198-4207. [CrossRef]

41. Yates, J.; Daiyan, R.; Patterson, R.; Egan, R.; Amal, R.; Ho-Baille, A.; Chang, N.L. Techno-economic Analysis of Hydrogen Electrolysis from Off-Grid Stand-Alone Photovoltaics Incorporating Uncertainty Analysis. Cell Rep. Phys. Sci. 2020, 1, 100209. [CrossRef]

42. Gallardo, F.I.; Ferrario, A.M.; Lamagna, M.; Bocci, E.; Garcia, D.A.; Baeza-Jeria, T.E. A Techno-Economic Analysis of solar hydrogen production by electrolysis in the north of Chile and the case of exportation from Atacama Desert to Japan. Int. J. Hydrogen Energy 2021, 46, 13709-13728. [CrossRef]

43. Gibson, T.; Kelly, N. Optimization of solar powered hydrogen production using photovoltaic electrolysis devices. Int. J. Hydrogen Energy 2008, 33, 5931-5940. [CrossRef]

44. Levene, J.I.; Mann, M.K.; Margolis, R.M.; Milbrandt, A. An analysis of hydrogen production from renewable electricity sources. Sol. Energy 2007, 81, 773-780. [CrossRef]

45. Haider, S.A.; Sajid, M.; Iqbal, S. Forecasting hydrogen production potential in islamabad from solar energy using water electrolysis. Int. J. Hydrogen Energy 2021, 46, 1671-1681. [CrossRef]

46. Parra, D.; Valverde, L.; Pino, F.J.; Patel, M.K. A review on the role, cost and value of hydrogen energy systems for deep decarbonisation. Renew. Sustain. Energy Rev. 2019, 101, 279-294. [CrossRef] 
47. Rahil, A.; Gammon, R. Dispatchable Hydrogen Production at the Forecourt for Electricity Demand Shaping. Sustainability 2017, 9, 1785. [CrossRef]

48. Ahshan, R.; Al-Abri, R.; Al-Zakwani, H.; Ambu-saidi, N.; Hossain, E. Design and Economic Analysis of a Solar PV System for a Campus Sports Complex. Int. J. Renew. Energy Res. 2020, 10, 67-78.

49. García, M.A.; Balenzategui, J. Estimation of photovoltaic module yearly temperature and performance based on Nominal Operation Cell Temperature calculations. Renew. Energy 2004, 29, 1997-2010. [CrossRef]

50. Perez, R.J.E. Analysis of the Levelized Cost of Green Hydrogen Production for Very Heavy Vehicles in New Zealand. Master's Theses, Victoria University of Wellington, Wellington, New Zealand, 2020.

51. RETScreen-Climate Database, Managed by CanmetENERGY Varennes Research Centre. Available online: https:/ /www.nrcan.gc $\mathrm{ca} /$ maps-tools-and-publications/tools/modelling-tools/retscreen/7465/ (accessed on 12 April 2021).

52. Masters, G.M. Renewable and Efficient Electric Power Systems; John Wiley \& Sons: Hoboken, NJ, USA, 2013.

53. The World's Most Efficient and Reliable Electrolysers. Available online: https://nelhydrogen.com/water-electrolysers-hydrogengenerators / (accessed on 13 June 2021).

54. Al-Badi, A.H. Performance assessment of $20.4 \mathrm{~kW}$ eco-house grid-connected PV plant in Oman. Int. J. Sustain. Eng. 2020, 13, 230-241. [CrossRef]

55. de Lima, L.C.; Ferreira, L.D.A.; Morais, F.H.B.D.L. Performance analysis of a grid connected photovoltaic system in northeastern Brazil. Energy Sustain. Dev. 2017, 37, 79-85. [CrossRef]

56. Attari, K.; Elyaakoubi, A.; Asselman, A. Performance analysis and investigation of a grid-connected photovoltaic installation in Morocco. Energy Rep. 2016, 2, 261-266. [CrossRef]

57. Padmavathi, K.; Daniel, S.A. Performance analysis of a 3MWp grid connected solar photovoltaic power plant in India. Energy Sustain. Dev. 2013, 17, 615-625. [CrossRef]

58. Bristowe, G.; Smallbone, A. The Key Techno-Economic and Manufacturing Drivers for Reducing the Cost of Power-to-Gas and a Hydrogen-Enabled Energy System. Hydrogen 2021, 2, 273-300. [CrossRef]

59. Hossain, E.; Faruque, H.M.R.; Sunny, M.S.H.; Mohammad, N.; Nawar, N. A Comprehensive Review on Energy Storage Systems: Types, Comparison, Current Scenario, Applications, Barriers, and Potential Solutions, Policies, and Future Prospects. Energies 2020, 13, 3651. [CrossRef]

60. Haszpra, L.; Ferenczi, Z.; Barcza, Z. Estimation of greenhouse gas emission factors based on observed covariance of CO2, CH4, N2O and CO mole fractions. Environ. Sci. Eur. 2019, 31, 1-12. [CrossRef] 